\title{
Acerca das Formas de Tratamento: cortesia e intimidade nas Crónicas de Fernão Lopes
}

\author{
António Santos Leite \\ antonio.santos.leite@outlook.com
}

\section{Resumo}

Este artigo procura analisar todas as formas de tratamento - nominais, pronominais e vocativas — identificadas e recenseadas nas crónicas de Fernão Lopes de modo a perscrutar a orgânica interna da sociedade em que o cronista se moveu e acerca da qual escreveu. Atentou-se a quem tratou quem, de que modo e com que forma, a fim de trazer à tona as mais variadas demonstrações de respeito e reverência, apreço e cumplicidade ou cortesia e intimidade. Assinalaram-se, sobretudo, as formas de tratamento de uso quotidiano, mas também as empregues em preces e orações, e aquelas formulares replicadas nos endereçamentos. Além disso, materializou-se uma breve história de cada tratamento. Os três principais vetores desta apuração foram os tratamentos, os interlocutores e as circunstâncias. Daí que se tenha observando também a direção e as ascendências dos tratamentos. Se de proximidade ou de distância, se hierárquicas ascendentes ou descendentes, notando como os pais eram tratados pelos filhos, os reis pelos súbditos, etc. Se é a primeira impressão a que fica, então a adequação da forma de tratamento empregue para com o interlocutor serve de bom ou mau cartão de visita.

Palavras-chave: formas de tratamento, sociedade medieval portuguesa, crónicas de Fernão Lopes.

\begin{abstract}
This article seeks to analyse all forms of address - nominal, pronominal and vocative - identified and recorded in the Fernão Lopes's chronicles in order to scrutinise the internal organisation of the society in which the chronicler moved and wrote. Attention was paid to who treated whom, in what way and with what form, in order to bring out the most varied demonstrations of respect and reverence, appreciation and complicity or courtesy and intimacy. Above all, the forms of address for daily use were highlighted, but also those used in prayers and supplications, and those formulas replicated in the addresses. Also, a brief history of each treatment was given. The three main vectors of this investigation were the addressing, the interlocutors and the circumstances. We also observed the direction and ascendancy of the treatments, noting, e.g., how parents were treated by their children, kings by their vassals. If this is the first impression that remains, then the appropriateness of the address used for the interlocutor serves as a good or bad presentation card.
\end{abstract}

Keywords: forms of address, Portuguese medieval society, Fernão Lopes's chronicles. 


\section{Introdução}

Imagine-se a sociedade medieval portuguesa como um organismo complexo, como um corpo de diversos membros do qual o rei era cabeça. Por mais relevantes que fossem todos esses membros, porém, havia sempre uns mais proeminentes do que outros e que buscavam diferenciar-se. Mais do que mera vaidade, é provável que todos esperassem que assim fosse, porquanto diferenciação era sinónimo de afirmação. É precisamente por isso que vários foram os elementos concorrendo entre si com esse fito, como sejam o modo de falar, estar, comportar, vestir, comer ou andar. Isto é tão verdade que, depois, o que as pragmáticas contra o luxo vieram dizer e Gil Vicente caricaturar, foi que ninguém podia parecer mais do que aquilo que era, distorcer a hierarquia e perturbar a ordem. Verdadeira sociedade de representações, tudo eram linguagens verbais e não-verbais de distinção, de que as formas de tratamento são particular reflexo.

Se se questionar o porquê de estudar as formas de tratamento no geral e na sociedade medieval portuguesa em particular, observa-se que, mais ontem do que hoje, elas revelavam a estruturação da sociedade, a hierarquia, as ascendências. Isto para não considerar o filão que são para estudos teóricos, formalistas e experimentais, de âmbito linguístico-filológico, sociolinguístico, pragmático, psicológico, antropológico, com a temática da manutenção da face positiva, ou filosófico, com a intencionalidade dos atos de fala. É que a linguagem é um fenómeno psicológico e social, e as formas de tratamento "uma zona sensível de mudança linguística por estarem muito dependentes de variáveis sociais em plena evolução"1. Além disso, é de conhecimento geral que o português possuiu um dos inventários de formas de tratamento mais complexos. Com efeito, as formas de tratamento não são nem inocentes nem ingénuas, antes cuidadosamente inseridas num formulário e empregues segundo os interlocutores e as circunstâncias circundantes.

O que se pretende neste artigo é observar, por sucessivas aproximações, as formas de tratamento seriadas nas crónicas de Fernão Lopes de modo a vislumbrar a orgânica interna da sociedade em que o cronista se moveu e acerca da qual escreveu. Trazer à tona as mais variadas demonstrações de cortesia ou intimidade, de maneira a assinalar formas que escapem ao paradigma daquelas repetidas infindáveis vezes pelos formulários da documentação oficial, apesar de também se observar essas e os tratamentos em orações. Ressalve-se, porém, que ao escrever em retrospetiva, Fernão Lopes escrevia segundo os moldes da sociedade em que vivia, pelo que as formas de tratamento são as da sua época, não da anterior, mesmo que atribuídas a falantes mais antigos. É que ele apenas pode ter vivenciado alguns dos eventos que descreveu na crónica de D. João I e contactado com quem os viveu. Assim, os tratamentos que vai colocando na boca dos seus intervenientes são próprios de um paradigma dos

\footnotetext{
${ }^{1}$ DUARTE, Isabel Margarida - Formas de Tratamento em Português: entre Léxico e Discurso. p. 87.
} 
séculos XIV-XV, o que até pode ter um interesse especial, não fosse essa uma época de substituição da elite dirigente e, a nível linguístico, perfazer o período de transição que a Esperança Cardeira entendeu como o "Português médio", entre o "antigo" ou "arcaico" e o "clássico" ou "moderno"2. Em todo o caso, também não se deve descurar a possibilidade do cronista ter adaptado o seu discurso ao registo de épocas anteriores à semelhança do que se passa no teatro, por exemplo.

\section{Fontes, metodologia e terminologia}

No que se refere às fontes, o presente estudo tem como corpus as formas de tratamento coligidas em quatro crónicas de Fernão Lopes, a saber, a de D. Pedro I, D. Fernando I, D. João I e a chamada Crónica de Portugal de 1419. Fiar-se-á que esta última provém de Fernão Lopes, apesar das várias mãos que nela participaram em conformidade com Filipe Alves Moreira ${ }^{3}$.

Não sendo a fonte ideal para o estudo das formas de tratamento, assuma-se, as crónicas não deixam de ter assinalável valência por reproduzirem diálogos ocasionais e cartas ou ofícios que doutro modo estariam perdidos. Apesar de alguma documentação oficial conservar certas formas em pequenas transcrições de diálogos, a utilidade limita-se, contudo, a permitir a aferição da evolução na longa duração das fórmulas. Para este estudo colheram-se 1184 registos. Não são muitos porque a heterogeneidade não é elevada. Mas também não são poucos porque, muitas vezes, mesmo dentro de um registo há várias formas de tratamento que não faria sentido particionar. A seriação foi feita com o registo da crónica, página, capítulo e linha, transcrição e tipologia da forma, interlocutores, cronologia e local de ocorrência, possíveis gestos associados e observações genéricas. A ação de catalogar não deixa de ser contraditória, dado que são expressões originalmente de distinção, com todas as suas nuances e gradientes, a serem encaixadas num mesmo molde na tentativa de as normalizar para melhor interpretar. Outra situação prende-se com certa ambiguidade na classificação de um tratamento como oral ou escrito.

O que se entende por forma de tratamento? Essa problemática tem sido tão prolixa como discordante. A generalidade dos autores dista entre a maior e a menor abrangência. Para alguns, só podem ser vocábulos ou locuções que, por persistirem no tempo, conquistaram a condição de nome geral. Para outros, somente pronomes e nomes. Outros incluem vocativos, perífrases e apóstrofes. Para uns pode ser qualquer expressão flagrada no trato com outra pessoa. Para outros somente aquelas que deram prova do tempo. Acima desta divisão podiam ainda ser divididos em tratamentos nominais, pronominais e verbais. Quanto aos destinatários, uns defendem que só existem formas de tratamento enquanto tal em alocuções, isto é, o tratamento para com aquele a quem se fala. Outros incluem delocuções, isto é, a forma de tratamento de quem se fala, referencial a uma terceira pessoa; e até em elocuções, que é o tratamento dado pelo locutor a si próprio. Também há quem faça distinção entre tratamento

\footnotetext{
${ }^{2}$ CARDEIRA, Esperança - Revisitando a periodização do Português: o Português Médio. pp. 103-114.

${ }^{3}$ MOREIRA, Filipe Alves - A Crónica de Portugal de 1419: fontes, estratégias e posteridade.
} 
direto - segunda pessoa do singular, semidireto - segunda pessoa do plural, e indireto - terceira pessoa do singular. Outra faceta da discussão passa pela posição da forma nas frases, e outra a partir do ponto de vista pragmático. Apesar disso, atentar-se-á às formas pronominais, nominais e vocativas em alocuções. Poder-se-á fazer nota de formas referenciais para com a terceira pessoa, bem como de formas de tratamento em diferentes posições na frase ${ }^{4}$. Não se atentou particularmente às formas gramaticalizadas ou verbais, e excluiu-se designativos como el-rey. Seguindo o raciocínio de Said Ali, atentar-se-á a qualquer substantivo de significação geral, que muitas vezes se transformam "em verdadeiros pronomes só por adquirirem um sentido geral"5. Um outro embate que mereceria um tópico exclusivo para discussão prende-se com as implicações das designações de forma ${ }^{6}$ ou fórmula $^{7}$ de tratamento, para sequer entrar na discussão da definição de tratamento $^{8}$ ou cortesia ${ }^{9}$. Ao assumir-se a preferência por forma, pretende-se sistematizar as expressões que se assumem como tratamento para com alguém, sejam elas momentâneas ou recorrentes, e os comportamentos associados. Enquanto se tem por fórmulas meras expressões reguladas, formas não só englobam as primeiras, como têm a valência de conter os aspetos relacionados com a mímica que acompanha e sucede a fala. Se uma fórmula é uma forma de tratamento, uma forma não é sempre uma fórmula.

No que se refere à bibliografia acessória, ainda está por fazer uma verdadeira história das formas de tratamento. Por conta disso, para além de dois trabalhos verdadeiramente notáveis, restam apenas capítulos de obras gerais ou artigos extremamente especializados. Ainda assim é mister mencionar a obra de Luís Filipe Lindley Cintra, Sobre «Formas de Tratamento» na Língua Portuguesa, e a de Marilina dos Santos Luz, Fórmulas de Tratamento no Português Arcaico.

\footnotetext{
${ }^{4}$ Como CARREIRA, Maria Helena Araújo - Formas de Tratamento no Português como Designação do Outro e de Si.

${ }^{5}$ SAID ALI, Manuel - Os pronomes: espécies, formas e significação. p. 92.

${ }^{6}$ No Grande Dicionário da Língua Portuguesa, forma define-se como "Constituição, modo particular de ser (...); Modelo, exemplar, norma (...); Modo, maneira de agir (...); Palavra, vocábulo (...); Estrutura, arranjo e estilo em composição literária (...)”. Cf. SILVA, António de Morais - Grande Dicionário da Lingua Portuguesa. vol. V. pp. 279-280.

${ }^{7}$ No Grande Dicionário Houaiss da Língua Portuguesa, fórmula define-se como "palavra ou expressão consagrada pelo uso e imposta por regras de etiqueta, convenções, costumes (...)", "frase ou expressão cristalizada, cujo sentido geralmente não é literal; chavão, frase feita, lugar comum, cliché (...)", "modo de proceder; método, norma, processo (...)". Cf. HOUAISS, Antônio; VILLAR, Mauro de Salles - Grande Dicionário Houaiss... vol. III. p. 1885.

${ }^{8}$ A "maneira pela qual o sujeito se dirige ao seu interlocutor". Cf. TEYSSIER, Paul - História da Língua Portuguesa. p. 72. "Usar de tratamento, bom ou mau, para; portar-se ou proceder bem ou mal para com alguém ou em relação a alguém (...); Travar relações com; conversar (...); Dar certo título ou tratamento a (...); Discorrer, falando ou escrevendo (...)". Cf. SILVA, A. de M. - Grande Dicionário Houaiss... vol. XII. p. 169. E "maneira de receber ou de ser recebido; acolhimento, receção (...)", "título honorífico ou de graduação (...)", "forma de referência ao interlocutor na situação escritor/leitor ou falante/ouvinte, muitas vezes especial, hierárquica ou protocolar (...)". Também são descritos os tratamentos para com autoridades, bem como o estilo a empregar e os tratamentos em situações de respeito e cortesia; os tratamentos de acordo com a aproximação por faixa etária, familiar e quotidiana. Cf. HOUAISS, A.; VILLAR, M. de S. - Grande Dicionário Houaiss... vol. V.p. 3763.

${ }^{9}$ Há distinção entre cortesia e cortesia linguística. Não havendo aqui espaço útil, observe-se uma síntese bastaste esclarecedora em CAVALHEIRO, Valéria Mourales - As diferentes regras de uso das formas tu e você e suas influências na compreensão de narrativas literárias: $P B$ e PE. pp. 66-86. Ao que parece, só no século XIII é que cortesia passou a estar identificada como, por um lado, com "moradia de um soberano", e por outro, com "um conjunto de pessoas da nobreza, pessoas que visitavam a moradia de um soberano". Assim, a noção de cortesia está marcadamente associada aos valores ditos nobres.
} 


\section{Fernão Lopes}

São escassas as informações sobre a vida de Fernão Lopes, mas acredita-se que tenha nascido entre $1380-90^{10}$. De origem humilde, vilã, foi casado e teve pelo menos um filho. Gomes Eanes de Zurara descreveu-o como "huma notavel pessoa, homem de communal sciencia e grande autoridade" ${ }^{" 11}$. É expectável que fosse tabelião e que tenha sido por essas funções que se aproximou da Coroa, dado que veio a ser escrivão dos infantes D. Fernando e D. Duarte. Desde 1418 foi encarregado por D. João I de "guardar as Escrituras do tombo, que estavão na Torre do Castello da Cidade de Lisboa". Feito rei, D. Duarte incumbiu-o "de poer em caronyca as estorias dos Reys que antygamente em Portugal forom; esto meesmo os grandes feytos e altos do muy vertuosso, e de grandes vertudes elRey seu senhor e padre". Em 1454, depois de "trinta e seis annos de serviço (...), deo Fernão Lopes hum notavel exemplo de honra, e de desinteresse, pedindo a demissão daquelle emprego; a qual lhe concedeo ElRei D. Afonso V nomeando seu sucessor a Gomes Eanes de Zurara, e declarando na mesma Carta de nomeação, que por ser o dito Fernão Lopes já tam velho e flaco, que per si não pode bem servir o dito officio, o dava a outrem per seu prazimento, e por fazer a Elle merce, como he razom de se dar aos boos servidores". Quer tenha pedido escusa ou sido dispensado, supõe-se que após cerca de vinte anos dedicado às crónicas, tenha então parado. O seu desaparecimento é apontado para pouco depois, mas ainda se crê vivo em 1459, quando foi beneficiado em carta por D. Afonso V. ${ }^{12}$

O seu prestígio garantiu-lhe a participação numa certa "atmosfera de progresso intelectual". Por conta disso, teve acesso a uma vasta biblioteca, e o seu ponto de vista segue um modelo teleológico. Primeiro cronista do reino, não era, porém, um mero compilador. Grande parte da sua obra resultou de um nexo metodológico, com recolha, seleção e crítica de fontes, num "escrupuloso respeito" pelas mesmas. Segundo Peter Russell, na Torre do Tombo aproveitou para reconstituir "a «verdadeira história» de que tanto fala""13 "transcrevendo, resumindo e aproveitando correspondência diplomática, os diplomas legais, os capítulos das Cortes, e outra documentação, que ainda enriqueceu (...) nos cartórios das igrejas e lápides de sepulturas (...) notando as suas contradições e inverosimilhanças, e decidindo-se (...) pela visão que julga «mais chegada à razão»"14 . Todavia, "ao interpretar os acontecimentos de que se tornou «repórten», Fernão Lopes interveio diretamente sobre eles" para "justificar os acontecimentos verificados em Portugal em 1383-85 (...) visando legitimar o comando político

\footnotetext{
${ }^{10}$ SARAIVA, António José - 2. ${ }^{\text {a }}$ Época - De Fernão Lopes a Gil Vicente. Capítulo III - Fernão Lopes. In SARAIVA, A. J.; LOPES, Óscar - História da Literatura Portuguesa. p. 121.

${ }^{11}$ ZURARA, Gomes Eanes de - Crónica da Tomada de Ceuta. pp. 11-14.

${ }^{12}$ MORATO, Francisco Manoel Trigozo D’Aragão - Discurso Preliminar, e Introdução ás Chronicas de Fernão Lopes. In ACADEMIA REAL DAS SCIENCIAS, Commissão de Historia. Collecção de Livros Ineditos de Historia Portugueza, dos Reinados de D. Dinis D. Affonso IV. D. Pedro I. e D. Fernando. Tomo IV. pp. XI-XVIII.

${ }^{13}$ RUSSEL, Peter - As Fontes de Fernão Lopes. pp. 6-9.

${ }^{14}$ SARAIVA, A. J.; LOPES, Óscar - História da Literatura Portuguesa. p. 124.
} 
vigente na primeira metade do séc. $\mathrm{XV}^{\prime 15}$. Do seu labor resultaram, indubitavelmente, as crónicas de D. Pedro I, D. Fernando I e a de D. João I. Contudo, a incumbência para escrever sobre os reinados anteriores ao de D. Duarte, e as remissões que vai fazendo a textos de reinados passados, deu azo à caça ao tesouro das suas “crónicas perdidas”. É aí que se enxerta a Crónica de Portugal de 1419, que se para uns não é da autoria de Fernão Lopes, para outros, como Filipe Alves Moreira, é.

\section{Formas de tratamento}

Nesta parte pretende-se expor os dados recolhidos e analisá-los, ver os interlocutores, as circunstâncias, e fazer a história de cada um dos tratamentos. Junto a cada tópico serão dados alguns exemplos dos dados seriados, posto que seria impraticável reproduzi-los todos aqui. Uma avaliação quantitativa é apresentada nos quadros em anexo.

\subsection{Vós}

O emprego da forma pronominal de tratamento vós provém do latim vos. Primitivamente existia apenas enquanto plural correspondente à $2^{\mathrm{a}}$ pessoa do singular $t u$. Depois o vós passou a ser usado também para com uma só pessoa, sendo que o momento exato em que essa mudança se deu está envolto em obscuridade. Para a generalidade dos autores é indiscutível que vós no singular tenha sido primeiro empregue em relação ao Imperador. Contudo, discordam se por sua iniciativa ou se dos súbditos para consigo. Segundo Roger Brown e Albert Gilman, há por um lado a possibilidade desse tratamento ter surgido depois da divisão administrativa do Império Romano em 293, a partir de quando dirigir-se a um Imperador implicou, implicitamente, dirigir-se aos dois, ao do Ocidente e ao do Oriente; por outro lado, há a hipótese de o Imperador ao assumir-se como pluralidade, no sentido de que é o conjunto daqueles que lidera, por eles falando e usando o nós majestático, o que explica a opção pelo vós numa iniciativa popular, de baixo para cima $^{16}$.

Já segundo António de Vasconcellos, o arrogo do nós pelas “auctoridades mais elevadamente collocadas" com o fito de dar aos seus atos "apparéncia de um decreto impessoal ou collectivo, como se decretasse em nome de todos e fôsse intérprete da vontade ou conveniéncia da sociedade", levou ao uso do vós por parte dos súbditos, "vulgarizando-se esta fórmula de tratamento, primeiro entre os inferiores em relação ao superior, depois entre eguais, e por fim mesmo de superiores para com inferiores" ${ }^{17}$. Para Marilina dos Santos Luz, o vós plural assumiu a faceta de pronome de cortesia na sequência do arrogo do nós majestático de Diocleciano face

\footnotetext{
${ }^{15}$ MONTEIRO, João Gouveia - Fernão Lopes, Texto e Contexto. pp. 15; 115 (referência correta apesar da numeração).

${ }^{16}$ BROWN, Roger; GILMAN, Albert - The Pronouns of Power and Solidarity. pp. 254-255.

${ }^{17}$ VASCONCELLOS, António Garcia Ribeiro de - Grammática histórica da língua portuguesa. p. 211.
} 
ao $e u$, estendendo-se a partir século VI ao ponto de no período imediatamente à formação das línguas românicas ter descido até às "classes sociais mais baixas" ${ }^{18}$. Lindley Cintra fez remontar o duplo emprego do vós, singular de cortesia e plural de indiferença, ao latim tardio ${ }^{19}$. Leonardo Lennertz Marcotulio afirma que o vós singular assumiu, num primeiro momento, um “conteúdo semântico de cortesia e distanciamento, associado à figura de maior prestígio da sociedade romana" ${ }^{20}$, sendo paulatinamente alargado, esvaziando-se da cortesia que lhe era inerente.

Quer vós derive, portanto, do emprego do nós majestático ou de um mais ambíguo de modéstia, empregue para com uma só pessoa parece estar associado ao surgimento da inclinação de demonstração de cortesia, respeito ou reverência. É como se sentisse, em determinado momento, que $t u$ era demasiado próximo ou invasivo para com quem se falava, e se buscassem estratégias no sentido de haver maior pejo ou distância para com o interlocutor. Contudo, não se tratando o outro como estranho ou desconhecido, usou-se da vaidade humana como forma tácita de aproximação aplicando vós no sentido de que este encarnava "a possibilidade de convencer aquele a quem era dirigido de que a sua pessoa era suficientemente importante para receber dos outros as homenagens a que tinha direito" ${ }^{21}$. Said Ali descreveu-o como uma "simples prova de respeito e polidez, depois de apagada na memória a imagem da situação primitiva" ${ }^{22}$. A verdade é que com esta primeira mutação o tratamento já se tornou um pouco menos direto, dado que se relativizou ou despersonalizou a pessoa com quem se fala. ${ }^{23}$

No tempo da redação das crónicas por Fernão Lopes, vós era o tratamento por excelência. Porém, daí em diante o duplo uso singular-plural do vós encontrou vários caminhos, ao ponto de Lindley Cintra asseverar que é difícil saber o seu verdadeiro valor. Certo é que não foi sempre o mesmo durante toda a Idade Média. Porém, esse tempo parece um ponto de chegada, com vós bastante difundido e amplo, vislumbrando-se já a estratégia nominal identificada por vários autores que vingou pouco depois, e que passava pelo isolar de uma característica do interlocutor.

Ora, dentre o corpus seriado há variados empregos do vós e dos seus derivados tanto no singular como no plural. O singular "tam elegante" no dizer de Cláudio Basto ${ }^{24}$, é normalmente usado de igual para igual ou de inferior para superior. Já o plural é usado de superior para

\footnotetext{
${ }^{18}$ LUZ, M. S. - Fórmulas de Tratamento no Português Arcaico. pp. 25-27, 30.

${ }^{19}$ CINTRA, L. F. L. - Sobre «Formas de Tratamento» na Lingua Portuguesa. p. 17.

${ }^{20}$ MARCOTULIO, Leonardo Lennertz - Formas de tratamento no português arcaico. pp. 158-159.

${ }^{21}$ LUZ, M. S. - Fórmulas de Tratamento no Português Arcaico. p. 26.

${ }^{22}$ SAID ALI, Manuel - Os pronomes: espécies, formas e significação. p. 93.

${ }^{23}$ Leonardo L. Marcotulio chama atenção para algo importantíssimo, sobretudo para a evolução da sintaxe, com as devidas implicações no campo dos tratamentos, que é o facto de que de apesar do vós passar a ser usado para com um só interlocutor ter mantido a sua concordância verbal ao nível da $2^{\mathrm{a}}$ pessoa do plural. Cf. MARCOTULIO, L. L. - Formas de tratamento no português arcaico... p. 158.

${ }^{24}$ BASTO, Cláudio - Formas de tratamento, em português. p. 193.
} 
inferior porque não tem qualquer conotação reverencial, antes é indiferente, igualitário ou neutral. Tanto surge o pronome vós expresso sem mais, antecedido de preposição, depois do vocativo Senhor, sob a forma de pronome oblíquo ou de adjetivo possessivo. Este último, mais adiante no tempo, serviu de base para os tratamentos nominais.

No seguinte exemplo, Teotónio, prior de Santa Cruz de Coimbra, dirige-se a D. Afonso Henriques. Repare-se que é um caso com o pronome vós singular, dirigido ao rei, mas os verbos no plural. Também há um adjetivo possessivo feminino vossa:

Vós destes a esta vosa igreja a vila de Leyria quando a tomastes aos mouros $(\ldots)^{25}$.

Noutro caso tem-se o autêntico vós de cortesia. É D. Afonso IV a falar com um bispo, Bernardo, enviado pelo Papa para solucionar o seu diferendo com Afonso XI:

Vós me falaes em teologya, e eu sey mays de beber que dela $(. . .)^{26}$.

Nos seguintes exemplos tem-se vós singular a seguir a um vocativo. No primeiro exemplo é um conselheiro a falar com D. Fernando, no segundo o condestável Nuno Álvares Pereira fala com um trombeta mensageiro:

Senhor, vós sabees bem como ja per vezes ouvestes $(\ldots . .)^{27} \mathrm{e}$

Amjgo, vos sejaes muyto vem vijndo $(\ldots)^{28}$.

Outros exemplos há do vocativo antes do vós, mas não são de cortesia.

Antecedido de preposição, vós aparece muitas vezes como no seguinte exemplo. Nele, Dona Beatriz, filha de D. João I, presta juramento pelas suas bodas com Thomas FitzAlan, conde de Arundel, na figura de um seu enviado, mosé Joham de Hueltesira:

Eu, dona Breatiz, per vos, mossee Joham Vel(te)sira $(\ldots)^{29}$.

A seguir nota-se o típico caso do vós no plural, bem com o pronome oblíquo vos. É o bispo de Lisboa a pregar aos cruzados a propósito da conquista de Alcácer do Sal:

Vós vedes bem quanto vos he o tempo aguora contrario e nam podês hyr tam çedo hu vós desejais e esto sabê vós $(. . .)^{30}$.

Até os reis tratavam os filhos por vós. Diz D. Afonso Henriques a D. Sancho: Filho, vós dizês muy bem $(\ldots)^{31}$.

\footnotetext{
${ }^{25}$ LOPES, F. - Crónica de Portugal 1419. Cap. 29; p. 33; linha 22.

${ }^{26}$ LOPES, F. - Crónica de Portugal 1419. Cap. 161; p. 260; linha 5.

${ }^{27}$ LOPES, F. - Crónica de D. Fernando. Cap. CXIV; p. 415; Linha 62.

${ }^{28}$ LOPES, F. - Crónica de D. João I - parte II. Cap. LV; p. 135; Linha 16.

${ }^{29}$ LOPES, F. - Crónica de D. João I - parte II. Cap. CCIV; p. 460; Linha 23. Na edição selecionada das I e II partes da Crónica de D. João I, provavelmente por opção, não se grafaram os acentos como no caso do vós, que aparece sempre vos.

${ }^{30}$ LOPES, F. - Crónica de Portugal 1419. Cap. 58; p. 106; Linha a confirmar.

${ }^{31}$ LOPES, F. - Crónica de Portugal 1419. Cap. 38; p. 68; Linha 12.
} 
Como se pôde observar, as variadas formas de vós e derivados tinham uma amplitude notável de interlocutores e situações de ocorrência. Como demonstração de respeito, reverência ou cortesia, ou seja, enquanto forma da 2. pessoa do singular, é usada sempre, no corpus seriado, de inferior para superior e de igual para igual, independentemente do estatuto social. A par do $t u$, vós é também muitas vezes auxiliar a outras formas de tratamento. No entanto, $t u$, vós e o próprio nome, são as únicas formas que podem ser usadas independentemente.

\section{2. $\mathrm{Tu}$}

O pronome de tratamento $t u$ tem uma história comum a vós. No latim primitivo, tu correspondia à $2^{\mathrm{a}}$ pessoa do singular e vós à $2^{\mathrm{a}}$ pessoa do plural. $T u$ era o único pronome conhecido da língua latina para tratar a $2^{\mathrm{a}}$ pessoa do singular. Na visão de António de Vasconcellos, nos primórdios da língua "quando alguém se dirigia o outrem, empregava sempre a $2^{\mathrm{a}}$ pessoa do singular, e usava no tratamento o pronome $t u$, qualquer que fôsse a sua categoria social (...). $\mathrm{O}$ tratamento de $t u$ não envolvia nenhuma idéia de familiaridade nem de superioridade relativa de quem o empregava" ${ }^{32}$. Depois, com o tempo e com o surgimento da consciência da inclinação para a cortesia e/ou reverência, vós invadiu o campo do $t u$, passando a poder designar também a $2^{\mathrm{a}}$ pessoa do singular e reduzindo a amplitude daquele, cada vez mais restrito à expressão da intimidade ou confiança extrema. Said Ali escreveu que o surgimento do vós para com uma só pessoa se deveu à insuficiência do $t u$ "para expressar o sentimento de humildade e respeito" 33 .

No entanto, para Marilina Luz, na Idade Média o tu ainda poderia ser um "prolongamento da tradição latina, tanto mais que o pronome $t u$, dirigido a superiores, sobrevive em alguns pontos do domínio românico" "34. Segundo a sua apuração nas crónicas de Fernão Lopes e Gomes Eanes de Zurara, só encontrou tratamentos empregando tu para com o rei em "circunstâncias especiais de apóstrofes" ${ }^{" 35}$. Contudo, na seriação que fundamenta o presente artigo foi possível encontrar algumas ocorrências em situações distintas do $t u$ e de formas vizinhas, como te, $t i$, etc.. A mais excecional por tudo o que a rodeia está plasmada mais adiante, numa carta do papa a D. Sancho II.

Às vésperas da conquista de Lisboa, um ermita dirige-se a D. Afonso Henriques:

Primçepe dom Afonso, Deos te envya dizer per mym que, porque tu ás grande vontade de o servir $(\ldots)^{36}$.

Os cavaleiros de D. Afonso Henriques tratam-no por: Senhor, tu não iras... ${ }^{37}$.

\footnotetext{
${ }^{32}$ VASCONCELLOS, A. G. R. - Grammática histórica da língua portuguêsa ... p. 210.

${ }^{33}$ SAID ALI, M. - Os pronomes: espécies, formas e significação. p. 94.

${ }^{34}$ LUZ, M. S. - Fórmulas de Tratamento no Português Arcaico. p. 49.

${ }^{35}$ LUZ, M. S. - Fórmulas de Tratamento no Português Arcaico. p. 49.

${ }^{36}$ LOPES, F. - Crónica de Portugal 1419. Cap. 14; p. 20; Linha 25.

${ }^{37}$ LOPES, F. - Crónica de Portugal 1419. Cap. 23; p. 41; Linha 4.
} 
Os pais tratavam os filhos por $t u$. No primeiro exemplo vê-se o pai de Nuno Álvares Pereira e no segundo D. Afonso Henriques para D. Sancho:

Nuno, pero tu sejas moço e de nova hidade, pareçeme que he bem e serviço de Deos e tua homrra, que tu ajas de casar (... $)^{38}$; e Filho, tu sabes bem quamto trabalho $(. . .)^{39}$. Segundo Marilina Luz, nesta sincronia, se "algum dia o rei falou por $t u$ à esposa, ou esta àquele, as crónicas não reproduzem tal tratamento". Na verdade, observando que as rainhas tratam os reis seus esposos por Senhor, supõe-se que "o único tratamento apropriado seria o vós" ${ }^{\prime 0}$. Todavia, há uma ocorrência de flagrante intimidade com emprego do $t u$, não entre dois casados, mas entre dois muito próximos, cuja relação a historiografia nacional muito proficuamente tratou. É uma fala de Dona Leonor Teles ao conde João Fernandes Andeiro:

"Toma tu o que te eu dou, e diga cada huu o que quiser (...)"41.

É evidente que neste exemplo se poderia desculpar ou compreender o excesso de confiança que levou ao tratamento por $t u$, se se tiver em conta a relação entre os dois, e o estado emocional momentâneo dos mesmos. A despeito dessa possível situação excecional, e atentando ao uso corrente do $t u$, este era usado de superior para inferior, entre iguais e íntimos. Noutro momento ainda o tratou pelo nome próprio ${ }^{42}$. Seja como for, ele tratava-a por senhora e neste passo o cronista faz questão de insinuar a intimidade entre ambos ${ }^{43}$.

\subsection{Vossa Mercê, Alteza, Senhoria e Majestade}

Vossa Mercê, Vossa Alteza, Vossa Senhoria e Vossa Majestade são formas nominais de tratamento segundo a classificação de Lindley Cintra. Posteriores às formas pronominais, são exceção no corpus em estudo. Temporalmente mais tardias, são formas já reveladoras de um maior distanciamento e a extrema cortesia para com quem se fala. Concomitantemente, distância e cortesia advinham do facto de implicarem o paulatino uso da $3^{a}$ pessoa gramatical do verbo, o que causou, para Marilina Luz, a "maior revolução do sistema do tratamento português"44. Observadas diacronicamente, o seu surgimento deveu-se à tendência para os tratamentos se tornarem progressivamente menos diretos ou mesmo indiretos.

\footnotetext{
${ }^{38}$ LOPES, F. - Crónica de D. João I - parte I. Cap. XXXIV; p. 60; Linha 12.

${ }^{39}$ LOPES, F. - Crónica de Portugal 1419. Cap. 38; p. 67; Linha 1. Os filhos replicaram senhor.

${ }^{40}$ LUZ, M. S. - Fórmulas de Tratamento no Português Arcaico. p. 223.

${ }^{41}$ LOPES, F. - Crónica de D. Fernando. Cap. CXLVI; p. 510; Linha 40.

42 “Johane, toma este anel”. Cf. LOPES, F. - Crónica de D. Fernando. Cap. CXLVI; p. 510; Linha 38.

43 "Senhora, mais chegado e mais husado queria eu de vós o pano, quando mo vós ouvessees de dar, que este que me vós daaes". Cf. LOPES, F. - Crónica de D. Fernando. Cap. CXXXIX; p. 488.

${ }^{44}$ LUZ, M. S. - Fórmulas de Tratamento no Português Arcaico. p. 49.
} 
Característica própria, todas estas formas partem do isolamento de uma qualidade atribuída primitivamente ao monarca: a generosidade, a alteza e o senhorio ${ }^{45}$. Said Ali escreveu que este tipo de tratamento "consistiu em fingir que se dirigia a palavra a um attributo ou qualidade eminente da pessoa de categoria superior, e não a ella própria" 46 . O modelo não era novo, antes transposto do latim, e até os termos em si podem ser considerados importados e adaptados de outros idiomas, como é o caso dos italianos alteza e senhoria, ou o castelhano mercê/merced ${ }^{47}$. Como quer que seja, estas formas da $3 .^{\mathrm{a}}$ pessoa do singular para a $2 .^{\mathrm{a}}$ pessoa vieram disputar o campo de emprego do vós da 2. ${ }^{\text {a }}$ pessoa do singular. Têm ainda a particularidade, como bem chamou atenção Cláudio Basto, de fazer concordância gramatical conforme o género do interlocutor a partir do possessivo, nunca do substantivo ${ }^{48}$.

Se de início "só se utilizam para o rei, para a rainha e para um duque estrangeiro (...), muito rapidamente se degradaram e o seu emprego se estende à nobreza e, a partir de certo momento, à alta burguesia”, destacou Lindley Cintra. Mais ainda, quem as adotou e propagou foi a "nova corte e a nova nobreza saídas da revolução de 1383-1385". Contudo, o lograr definitivo foi apenas com D. Afonso V, nomeadamente após a Batalha de Alfarrobeira, com o retorno da velha nobreza, quando os tratamentos nominais experimentaram um fenómeno de especialização, isto é, começou-se a "considerar a utilização de cada um deles como apropriada só para determinada ou determinadas camadas de entre aquelas em que se dividia a referida sociedade" ${ }^{49}$. A verdade é que pelos sucessivos alargamentos dos interlocutores possíveis, estas formas também sofreram desgaste, e foram sendo substituídas ou atualizadas.

Deve ainda registar-se que foi ao sucesso próximo da ampliação do uso das formas nominais de tratamento, inequivocamente de cortesia, que se deveu a diminuição do emprego do vós cortês da $2^{\mathrm{a}}$ pessoa do singular e do próprio vós neutral da $2^{\mathrm{a}}$ pessoa do plural ${ }^{50}$. Marilina Luz vai mais longe, e relata a paulatina sobreposição destas "fórmulas indiretas de tratamento" aos pronomes oblíquos vos e vós, ao pronome pessoal vós e até ao possessivo vosso ${ }^{51}$.

\subsubsection{Vossa Mercê}

Nas primeiras aparições, vossa mercê não desempenhava a função de sujeito. Antes era um artificio usado para destacar essa característica tão régia, a mercê, ou como forma de expressar

\footnotetext{
${ }^{45}$ CINTRA, L. F. L. - Sobre «Formas de Tratamento» na Língua Portuguesa. p. 18.

${ }^{46}$ SAID ALI, Manuel - Os pronomes: espécies, formas e significaçãoo. pp. 93-94.

${ }^{47}$ CINTRA, L. F. L. - Sobre «Formas de Tratamento» na Lingua Portuguesa. p. 19; 21.

${ }^{48}$ BASTO, C. - Formas de tratamento, em português... p. 185.

${ }^{49}$ CINTRA, L. F. L. - Sobre «Formas de Tratamento» na Lingua Portuguesa. p. 19-20.

${ }^{50}$ CINTRA, L. F. L. - Sobre «Formas de Tratamento» na Lingua Portuguesa. p. 30-31.

${ }^{51}$ LUZ, M. S. - Fórmulas de Tratamento no Português Arcaico. p. 57.
} 
a vontade real, de fazer um pedido ou agradecimento, cumprimentar, despedir, clamar por misericórdia. Aliás, a mercê não só era um atributo régio como também divino, a crer no dizer de um escudeiro que se coloca "aa merçee de Deos e vossa", em referência a Dona Beatriz, filha de D. Fernando e Dona Leonor Teles ${ }^{52}$.

No título XXIV da Terceira Partida de Afonso X, acerca da mercê que "demandan los homes á los reyes sobre los juicios que les dan de ninguno nos se puede alzar, et sobre otras cosas que los homes non puden nin deben haber sinon piedindo merced á los señores", define-se como "Tempramiento de la reciedumbre de la justicia es la merced: et nasce grant pro della; ca ella mueve á los reyes á piedat contra aquellos que la han meester, et la piden en tiempo et en sazon que lo deben facer" ${ }^{33}$. No glossário do Leal Conselheiro de D. Duarte, mercê é "merito, obra meritoria"54.

Said Ali descreveu o seu emprego do seguinte modo: "os súbditos, dependentes sempre da mercê ou graça do príncipe, apresentavam as suas queixas e requerimentos dando-lhe o habitual vós. Sabiamente pediram por mercê e punham frequentemente vossa mercê por vós, referindose não à pessoa do soberano, e sim à graça e favor que dele dimanava"55. Ou seja, vossa mercê não se refere ao rei, mas ao favor que ele concede. Nas crónicas de Fernão Lopes, inclusive, os pedidos são mesmo dirigidos a outros que não ao rei. Marilina Luz detetou algumas formas de mercê a não encarnar sujeito, a saber, pedir por mercê, seja vossa mercê, ter em mercê, encomendo-me em vossa mercê, vou-me com vossa mercê e beijo as mãos de vossa mercê ou envio beijar vossas mãos ${ }^{56}$.

Entretanto, para os efeitos deste estudo importa Vossa Mercê e as demais formas nominais como formas de tratamento. Importa a consubstanciação da graça que vinha do rei por meio da sua mercê na própria figura real. Ora, como se pode ver abaixo, era uma forma de tratamento empregue de inferiores para superiores. Nuno Álvares Pereira dirige-se a D. Fernando, dizendo:

Senhor, a vossa mercee saiba que por eu seer vosso creiado $(\ldots)^{57}$.

Vasco Gomez de Abreu interpela Dona Leonor Telles assim:

Ca bem sabe vosa merçee, quando tal guerra aqueeçer e se galles ham darmar, que de Castella vem os galyotes e os dinheiros $(. . .)^{58}$.

Segundo Marilina Luz, é provável que entre o primeiro quartel do século XIV ao primeiro do XV, "além de vós e senhor, o tratamento dado ao rei seria só vossa mercê". A partir daquela

\footnotetext{
${ }^{52}$ LOPES, F. - Crónica de D. João I - parte I. p. 234.

${ }^{53}$ AFONSO X - Las Siete Partidas del Rey Alfonso El Sabio... Tomo II. pp. 699-701.

${ }^{54}$ D. DUARTE - Leal Conselheiro, o qual fez Dom Duarte... p. 665.

${ }^{55}$ Cit. por LUZ, M. S. - Fórmulas de Tratamento no Português Arcaico. p. 57.

${ }^{56}$ LUZ, M. S. - Fórmulas de Tratamento no Português Arcaico. pp. 58-66.

${ }^{57}$ LOPES, F. - Crónica de D. Fernando. Cap. CXXIII; p. 437; Linha 12.

${ }^{58}$ LOPES, F. - Crónica de D. João I - parte II. Cap. CXLIV; p. 298; Linha 2.
} 
data surgiu vossa senhoria ${ }^{59}$. Vossa Mercê já nos fins do século XV estava a cair ao ser corrente para fidalgos e até inferiores, sendo substituída ou potenciando a sua substituição por Vossa Senhoria e Vossa Excelência, "formas associadas à cortesia, ao respeito, à «reverência»" "60.

\subsubsection{Vossa Senhoria}

Vossa Senhoria só aparece uma vez no corpus triado. É o doutor Álvaro Martiz, enviado de João de Castela, a falar com o Duque de Lencastre, onde diz:

— "Senhor, eu por parte del-Rey de Castella, meu senhor, (...) a esto respomdo que, salua vossa senhoria, vossa molher a Duquesa dona Costança nom ha em elles nenhuum dereito" ${ }^{61}$.

Marilina Luz não a encontrou no seu estudo. No entanto, como ela escreveu para um exemplo chancelar, parece uma expressão um tanto quanto deslocada. É no mínimo duvidosa, e muito provavelmente ainda pouco difundida, apesar do seu uso vingar nos séculos seguintes ${ }^{62}$. Por outro lado, há o uso da expressão voso senhorio ${ }^{63}$ em referência à posse de uma propriedade, não constituindo um tratamento.

\subsubsection{Vossa Alteza}

Vossa Alteza aparece algumas vezes. Duas delas por emprego de um bispo a dois monarcas, e uma terceira vez na boca dos conselheiros de João I de Castela. Como exposto anteriormente, este tipo de tratamento passa pelo isolar de uma característica da pessoa régia enquanto interlocutora. Neste caso tem-se "alteza", segundo Marilina Luz como qualidade do que é elevado, sendo até usada noutros momentos que não em tratamentos. Todavia, essa autora viu a presente forma com estranheza, escrevendo que "as circunstâncias em que são proferidas não são normais", crendo tratar-se de mera transcrição dos documentos, inferindo-o pela nacionalidade dos locutores: castelhanos e genoveses ${ }^{64}$. Neste caso, é comum associar-se muitas vezes o epíteto de "real", vossa real alteza. Bernardo, bispo de Rutonense, fala com D. Afonso IV, dizendo:

Porende a vosa alteza afincadamente envya rogar que, deixãodo todo odio e ramcor que a elrey de Castela temdes, venhaes com ele e bõa comcordia $(. . .)^{65}$.

Um conselheiro de João I de Castela disse-lhe:

E asy, Senhor, comcluindo nosso consselho, pydindo perdam a vosa Real Alteza (... $)^{66}$.

\footnotetext{
${ }^{59}$ LUZ, M. S. - Fórmulas de Tratamento no Português Arcaico. p. 72.

${ }^{60}$ CINTRA, L. F. L. - Sobre «Formas de Tratamento» na Lingua Portuguesa. p. 26-29

${ }^{61}$ LOPES, F. - Crónica de D. João I - parte II. Cap. LXXXV; p. 191; Linha 19.

${ }^{62}$ LUZ, M. S. - Fórmulas de Tratamento no Português Arcaico. pp. 74-75.

63 “Ao bõo e eiçelente e poderoso e mui temido senhor (...) Senhor, aquele Deos que pode vos deixe acreçemmtar vosa fama e reger por longos dias os regnos de Portugal e do Algarve e someter a voso senhorio teras de vossos inmiguos e seus corações”, escreveu João Manuel a D. Afonso IV. In LOPES, F. - Crónica de Portugal 1419. p. 237.

${ }^{64}$ LUZ, M. S. - Fórmulas de Tratamento no Português Arcaico. p. 77.

${ }^{65}$ LOPES, F. - Crónica de Portugal 1419. Cap. 163; p. 263; Linha 25.

${ }^{66}$ LOPES, F. - Crónica de D. João I - parte II. Cap. CXLIV; p. 299; Linha 10.
} 


\subsubsection{Vossa Majestade}

Vossa Majestade ou Vossa Real Majestade é mais um daqueles tratamentos estrangeiros. Encontra-se duas vezes nas crónicas de Fernão Lopes, pela boca do Duque de Génova e por um conselheiro de João I de Castela. Segundo Marilina Luz, na medievalidade "lembrar ao rei a sua majestade era divinizá-lo", engrandecê-lo. No entanto, assevera que originalmente, nos idos tempos imperiais, não havia qualquer ideia de grandeza implícita. Maiestas era um conceito político concretizado na Maiestas populi. Com o desgaste temporal, o conceito original foi progressivamente dando lugar a outro de matriz "pré-cristã". É a esta última "que se deve o prestígio histórico da maiestas romana". Porém, para o intervalo do corpus em estudo, ela disse que os dois conceitos de majestade divinal e real se tocaram, isto é, coexistiram, apesar de que "não se perdera a noção, ainda no século XV, de que a majestade é atributo de Deus" ${ }^{67}$ Como vossa alteza, seguia-se maioritariamente do epíteto real: vossa real alteza, vossa real majestade.

Para aquela autora, Vossa Alteza e Vossa Majestade não mais evoluíram desde que foram reservadas para a família real, enquanto Vossa Mercê, Senhoria e Excelência vulgarizaram-se e foram purgadas da realeza ${ }^{68}$. As outras foram alargando o seu uso, vulgarizando-se e caindo em desuso.

\subsubsection{Outras}

Vossa clareza e vossa nobreza são formas no mesmo molde das anteriores. Todavia, como são escassas não justificam um tópico individualizado. Apesar disso, aparecem no corpus analisado protagonizadas por estrangeiros e no registo escrito, sendo por isso contabilizadas como fórmulas.

Apesar de não haver exemplos de vossa excelência, é provável que essa forma fosse possível, mesmo que escassamente empregue, por extensão do processo de isolar uma característica e usá-la como tratamento, dado que Fernão Lopes escreveu algumas vezes acerca da qualidade do que é excelente, e que Marilina Luz a detetou em documentação chancelar ${ }^{69}$. O mesmo aconteceu para clareza e nobreza, qualidades presentes em correspondência de remetentes estrangeiros.

\subsection{Senhor}

Senhor é uma forma vocativa de tratamento. Na realidade é a forma vocativa por excelência, a mais abundante no corpus em estudo. Todavia, também poderia ser a forma nominal senhor ou a pronominal o senhor. A sua forma original latina era senior, que, porém, não era forma de tratamento. A sua transfiguração em tratamento provocou como que uma alteração em cadeia ao disputar uma função que era preenchida por dominus, que em português deu Dom. Segundo Marilina Luz, a substituição de dominus por senior efetuou-se com o aparecimento das línguas

\footnotetext{
${ }^{67}$ LUZ, M. S. - Fórmulas de Tratamento no Português Arcaico. pp. 81-84.

${ }^{68}$ LUZ, M. S. - Fórmulas de Tratamento no Português Arcaico. p. 129.

${ }^{69}$ LUZ, M. S. - Fórmulas de Tratamento no Português Arcaico. p. 86.
} 
românicas. A primeira significava dono, proprietário e a segunda homem velho. Diz essa autora que sendo a autoridade um dos atributos da idade, a identificação de senior com homem que tem autoridade foi natural. No entanto, o ponto de viragem do significado de cada termo parece estar associado à Igreja, que começou a usar senior para "exprimir o conceito de uma autoridade fraterna, como a que existe num irmão mais velho (...), acabando por ser um sinónimo de Deus"70. Frei Joaquim de Santa Rosa de Viterbo explicou essa questão no seu Elucidário: "sendo certo, que Senhores corresponde ao latino Domini, se manifesta, que o Dom presente, que se dá aos Conegos Regrantes, he abreviatura de Senhor antigo"71.

No 25. ${ }^{\circ}$ título da sua Quarta Partida, Afonso X escreveu acerca da relação entre senhores e vassalos. Na 1. lei pormenorizou que:

\begin{abstract}
Señor es llamado propriamente aquel que ha mandamiento et poderio sobre todos aquellos que viven en su tierra; et á este atal deben todos llamar señor, tambien sus naturales como los otros que vienen á él ó á su tierra*. Otrosi es dicho señor todo home que ha poderio de armar et de criar por nobleza de su linage; et á este atal no deben llamar señor sinon aquellos que son sus vasallos et resciben bienfecho dél. Et vassallos son aquellos que resciben honra et bienfecho de los señores, asi como cavalleria, ó tierra ó dineros por servicio señalado que les hayan de facer. ${ }^{72}$
\end{abstract}

Posto isto, é caso para concluir como Marilina Luz e considerar que, depois de Deus, o rei era "aquele a quem melhor adaptava o nome de senhor" ${ }^{\text {"73 }}$. Entretanto, talvez fosse pertinente observar a evolução do estatuto dos primeiros monarcas portugueses. É que os condes D. Henrique e D. Teresa receberam os condados portucalense e conimbricence como dote, mas também como forma de reforço da defesa desse território cada vez mais distante do centro do poder da Galiza. Segundo o José Mattoso, o que lhes foi concedido foi um senhorio precário com obrigação de vassalagem a Afonso VI, não à Galiza. Após o falecimento de D. Henrique em 1112, coube a D. Teresa a administração do território - pouco depois já se intitulava rainha. Contudo, a sua aproximação à Galiza não deixava antever bom futuro. Foi nesta conjuntura que D. Afonso Henriques foi ganhando protagonismo. No entanto, parece que desde o início ele apenas fora intitulado de infante e/ou príncipe, mas nunca de conde. Com essa designação invocava "a sua ascendência régia" porque neto do Imperador Afonso VI, apesar de ainda ser vassalo de Leão. Assim, é verdade que a independência do condado que se transformou em reino, e a passagem do infante e/ou príncipe — que nunca foi conde — a rei, foi morosa, mas entre 1139-1140 D. Afonso Henriques já ostentava o título de rei. ${ }^{74}$

\footnotetext{
${ }^{70}$ LUZ, M. S. - Fórmulas de Tratamento no Português Arcaico. p. 33-34

${ }^{71}$ VITERBO, Joaquim de Santa Rosa de - Elucidário das palavras, termos e frases que em Portugal antigamente se usaram e que hoje regularmente se ignoram. Vol. II, p. 208.

* Sublinhado inexistente no original, mas acrescentado a fim de frisar esse período.

72 AFONSO X - Las Siete Partidas del Rey Alfonso El Sabio... Tomo III. pp. 132-135.

${ }^{73}$ LUZ, M. S. - Fórmulas de Tratamento no Português Arcaico. p. 36.

${ }^{74}$ MATTOSO, José (dir.) - A monarquia Feudal, Vol. 2 de MATTOSO, J. e SOUSA, Armindo de, 'História de Portugal'. pp. 33-34; 54.
} 
Com a territorialização do poder e o deslocar para Coimbra, nova relação de forças se estabelecera. D. Afonso Henriques evoluiu de Primus inter pares para Primus super pares. Em crescendo, os seus sucessores foram aumentando, com avanços e recuos, a preponderância da coroa sobre o território e sobre as pessoas, de que é particular testemunho a evolução questionadora das Inquirições régias, mas só com D. João I é que se consumou em definitivo essa proeminência. Foi este monarca quem proibiu os senhores guerreiros que o acompanhavam de ter o seu próprio corpo de vassalos, passando todos a vassalos do rei. ${ }^{75}$

Desta evolução é particularmente interessante um momento em que entre diversos cavaleiros, um em seu nome, dirigiu-se a D. Afonso Henriques e chamou-o $t u$, algo impensável pouco depois $^{76}$. Noutra perspetiva, quando D. Sancho começou a ganhar protagonismo após o acidente do pai, foi logo chamado senhor ${ }^{77}$. Repare-se na progressiva acutilância do termo senhor, ganhando amplitude em termos de extensão e resiliência. Por tudo isto, o rei devia encarnar alguns princípios que o orientassem na relação com os seus súbditos: honrado, dotado de coragem e valentia, deveria ter-lhes amor e ser popular; promover atos de "boa ordem e bem-estar"; zelar pela manutenção do ordenamento social, instigar o enriquecimento do reino e, acima de tudo, ser justo, mas pio ${ }^{78}$.

Senhor era frequentemente a junção de autoridade e respeito, no caso do monarca, rei e senhor, podendo ser não só dirigido ao rei, apesar dele ser sinónimo, mas também a outros elementos hierarquicamente superiores ao locutor $^{79}$. É sabido o comum fenómeno da justaposição de Senhor + topónimo de que é detentor. Joseph-Maria Piel também notou o contrário, de que "desde que o mundo é mundo, o homem comprazeu-se em dar o seu nome à terra que ocupava e cultivava" ${ }^{\prime 0}$. Um testemunho da importância desta forma de tratamento foi dado por Nuno Álvares Pereira, quando rejeitou senhor antes de escolher os vassalos que o deveriam acompanhar, preferindo ser tratado pelo seu nome: "Nom me chamees senhor, (...) ca o nom som"

Enquanto vocativo, senhor podia vir acompanhado de adjetivos ou outros epítetos. Segundo Marilina Luz, esta forma "tinha suficiente conteúdo respeitoso para dispensar o auxílio de um título nobiliárquico, quando se dirigia a palavra a um nobre" ${ }^{" 82}$. A variedade e amplitude do uso de senhor são enormes. Em jeito de síntese, senhor associava-se a títulos de nobreza, dignidade, profissão, parentesco, antropónimo e até com possessivos e outros epítetos.

\footnotetext{
${ }^{75}$ MATTOSO, J. - A Monarquia Feudal... pp. 57-59.

76 “Senhor, tu não iras comnosquo (...)". Cf. LOPES, F, - Crónica de Portugal 1419. Cap. 23; p. 41 ; Linha 4.

${ }^{77}$ LOPES, F. - Crónica de Portugal 1419. Cap. 39; p. 70; Linha 18.

${ }^{78}$ BEIRANTE, Maria Ângela - As Estruturas Sociais em Fernão Lopes. pp. 16-21.

${ }^{79}$ LUZ, M. S. - Fórmulas de Tratamento no Português Arcaico. pp. 121-124.

${ }^{80}$ PIEL, Joseph-Maria - Nomes dos «possessores» latino-cristãos na toponímia asturo-galego-portuguesa. p. 145. Cit. por LUZ, Marilina..., p. 35.

${ }^{81}$ LOPES, F. - Crónica de D. João I - parte I. p. 63

${ }^{82}$ LUZ, M. S. - Fórmulas de Tratamento no Português Arcaico. pp. 125-126.
} 
No que se refere às mulheres, estas tanto podiam ser chamadas por senhora como por senhor. A flexão podia ou não acontecer. No fundo, parece que primitivamente a senhor ainda não se associava qualquer marca de género possibilitando a flexão, evoluindo posteriormente. $\mathrm{Na}$ poesia trovadoresca, por exemplo, pode observar-se que o poeta se dirige quase sempre à sua senhor. Disto é particular exemplo o facto de Dona Leonor Teles ter sido regedor e defensor do Reino, e noutros momentos: senhora. Marilina Luz questionou "se esse tratamento era simultaneamente dado às esposas (ou até às filhas) de todos os que podiam intitular-se senhores" ${ }^{\prime 3}$, comportamento que não foi encontrado. A despeito disso, a senhora também se podiam juntar possessivos ou adjetivos, como dona, que justaposta a senhora encontrava a sua mais respeitosa forma. Alguns exemplos:

Senhor monssé Beltram, el-rrei dom Pedro meu senhor $(. . .)^{84}$.

Até os cardeais em Roma se tratavam por $\operatorname{senhor}^{85}$. Para com o Papa foi:

Senhor santo padre, eu não diguo a carta $(\ldots)^{86}$.

Um tratamento extremamente honroso pode ser o do cardeal celebrante das bodas de João I de Castela com Dona Beatriz, filha de D. Fernando e Dona Leonor Teles:

Vós, senhor doom Joham, rrei de Castella e de Leom que presente estaaes (... $)^{87}$.

Como Marilina Luz notou e este estudo veio confirmar, senhor é preponderante no início das frases, apesar de aparecer noutras posições "sem que, para isso, pareça obedecer a qualquer propósito de ter o tratamento mais cortês" ${ }^{" 88}$. Para ela, senhor foi o tratamento mais usual para com o monarca durante o século XIII ${ }^{89}$. Mesmo com o proliferar das formas nominais como Vossa Mercê, não é de crer que senhor tenha perdido influência. Pelo contrário, é o mais comum em Fernão Lopes.

\subsection{Amigo}

Antes de qualquer outra consideração é preciso assinalar que tratar alguém por amigo tem, pelo menos, uma tripla conotação. Uma é legítima expressão de amizade; outra é no sentido de aliança por necessidade ou conveniência; e outra é num sentido de um pouco mais do que amizade, ou seja, uma relação amorosa. ${ }^{90}$ De facto, na Idade Média conjugar o verbo amigar era sinónimo de namorar ou, pelo menos, ter essa intenção. Aliás, deste verbo e deste tipo de relação são particularmente ilustrativas as numerosas Cantigas de Amigo. Porém, amigar não

\footnotetext{
${ }^{83}$ LUZ, M. S. - Fórmulas de Tratamento no Português Arcaico. pp. 165-166.

${ }^{84}$ LOPES, F. - Crónica de D. Fernando. Cap. XXII; p. 78; Linha 25. Repete-se na linha 47.

${ }^{85}$ LOPES, F. - Crónica de D. Fernando. Cap. CVII; p. 388; Linha 72. Repete-se na p. 389, linha 135.

${ }^{86}$ LOPES, F, - Crónica de Portugal 1419. Cap. 18; p. 32; Linha 3.

${ }^{87}$ LOPES, F. - Crónica de D. Fernando. Cap. CLXV; p. 568; Linha 38.

${ }^{88}$ LUZ, M. S. - Fórmulas de Tratamento no Português Arcaico. p. 42-43.

${ }^{89}$ LUZ, M. S. - Fórmulas de Tratamento no Português Arcaico. p. 37.

${ }^{90}$ No que se refere à conveniência, nem sempre era usada. Vide o exemplo do Infante D. João, fílho de D. Pedro I e Inês de Castro, que mesmo a necessitar de ajuda dos seus vassalos, nunca os tratou por amigos. Ver LOPES, F, - Crónica de Portugal 1419. Cap. CIII; p. 369; Linha 12. Ou p. 370, linha 32.
} 
era um estatuto definitivo e estável. Pelo contrário, o que as cantigas mostram é, precisamente, a pluralidade de estádios possíveis entre a amada e o amante. Segundo Marilina Liz, "Na Idade Média só o amor justificava as relações amigáveis entre os dois [homem e mulher], por isso uma palavra como amigo (-a) pôde sofrer esta evolução"91.

No corpus seriado são mais evidentes os dois últimos tipos de emprego de amigo. Curiosamente, parece que cada uma das tipologias está predominantemente associada a um tipo de ascendência. Esta forma de tratamento tanto pode ser nominal como vocativa, e não só surge sozinha como em conjunto com outro vocábulo, constituindo um único sintagma, e que poderia ser um adjetivo possessivo ou outro nome comum. Por conta de todas estas suas particularidades, amigo é uma forma transversal a quase todos os indivíduos. Tanto era dirigido pelo senhor aos seus vassalos e homens de armas, como a clérigos e a populares. Também surgiu a anteceder um antropónimo.

Segundo Marilina Luz, quando empregue de superior para inferior está-se perante um "sinal de condescendência afável"92. Demonstra-o um frade tratar um arcebispo por senhor, e este replicar amigo:

— Senhor, aquelles capitaães que alli (...); — Amigo (...) estas gemtes (...). ${ }^{93}$

Claro exemplo de solidariedade militar é o apelo de Nuno Álvares Pereira:

Amigos irmãaos, bem sabees a teençom com que sahistes da cidade (... $)^{94}$.

Noutro momento, o cronista escreveu que, quando a ação de um seu subordinado o desagradava, chamava-o por amigo: "Ho, amygo!"95.

Em momentos aflitivos, D.Afonso Henriques tinha o hábito de tratar os que consigo andavam por:

Amiguos, senhores, irmãoos (... $)^{96}$; Bons amiguos e vasalos, que coussas sam estas que dizees? $(\ldots)^{97}$; ou só amigo numerosas vezes.

Os cruzados combatentes em Lisboa bradavam: Ho, irmão, que em bõa ora vieste $(. . .)^{98}$.

Dona Isabel de Aragão, a Rainha Santa Isabel, dirigiu-se a uma mulher pedindo-lhe para lavar os seus pés, a que a outra respondeu: - Amigua, metede o pee no baçio e lavar-vo-lo-ei (...); - Senhor, nom vo-lo lixarei (...)..$^{99}$

Com um possessivo, Nuno Álvares Pereira responde a Vasco Martins do Outeiro: — Amigo meu, eu vos gradeço vosso bom comsselho (... ${ }^{100}$.

\footnotetext{
${ }^{91}$ LUZ, M. S. - Fórmulas de Tratamento no Português Arcaico. p. 183.

${ }^{92}$ LUZ, M. S. - Fórmulas de Tratamento no Português Arcaico. pp. 181-182.

${ }^{93}$ LOPES, F. - Crónica de D. João I - parte I. Cap. CXX; p. 206; Linhas 32 e 37.

${ }^{94}$ LOPES, F. - Crónica de D. Fernando. Cap. CXXXVIII; p. 433; Linha 15.

${ }^{95}$ LOPES, F. - Crónica de D. João I - parte II. Cap. CXCIX; p. 445; Linha 10.

${ }^{96}$ LOPES, F. - Crónica de Portugal 1419. Cap. 14; p. 22; Linha 14.

${ }^{97}$ LOPES, F. - Crónica de Portugal 1419. Cap. 33; p. 58; Linha 24.

${ }^{98}$ LOPES, F. - Crónica de Portugal 1419. Cap. 49; p. 92; Linha 21.

${ }^{99}$ LOPES, F. - Crónica de Portugal 1419s. Cap. 93; p. 168; Linhas 12 e 13.

${ }^{100}$ LOPES, F. - Crónica de D. João I - parte I. Cap. CLII; p. 282; Linha 18.
} 


\subsection{Dom e Dona}

Dom está evidentemente relacionado com o latim dominus, cuja história já foi repassada anteriormente a propósito do tratamento por senhor. Como se escreveu, consta que a sua antiquíssima forma latina foi como que reservada pela Igreja para Deus. No entanto, teve depois o seu uso alargado ao Papa e, depois, progressivamente até adentrar na esfera secular. Foi entre o século que, parece, adotou a feição de título nobiliárquico para além da anterior feição de cortesia.

No Vocabulario Portuguez e Latino de Rafael Bluteau, Dom é apresentado como título honorífico que "antigamente se dava só aos Reys, e seus descendentes, aos Ricos homens, e a cavaleiros que tinham privilégio Real por grandes serviços". Dom deriva de Domnus, abreviatura de Dominus, que se reservava ao Papa, mas que depois foi descendo conforme as dignidades eclesiásticas enquanto "Pronome honorífico". "Dizem que os primeiros Religiosos que tomaram este título, por humildade, não quiseram o de Dominus, que só pertence a Deos, senhor de todos os senhores, e que só admitiram o de Domnus, que denota inferioridade, como quem dissera, Minor Dominus". Em Portugal, diz o autor, fazia-se "tanta estimação deste título, que só era concedido pellos Reys a seus descendentes, e aos Ricos homens, e deles o tomavam seus filhos”. Por fim, atribuiu o primeiro uso de Dom na península ibérica a Dom Pelágio, rei dos Godos, após a morte do seu antecessor Rodrigo. Consta que depois fora regulado por Filipe II de Espanha, I de Portugal ${ }^{101}$.

De facto, são muitos os questionamentos acerca da amplitude e das condições de aplicação do Dom, quer como título quer como cortesia. A isso poder-se-iam somar as implicações de usar a forma por extenso ou abreviada. De certa maneira equivale a Senhor, mas com a propriedade de exigir o nome de quem é atribuído quando senhor não o exige. Todavia, é inegável a predominância de Dom enquanto título hierárquico. Por tudo isto, é evidente que é uma forma de tratamento empregue de inferiores para superiores e/ou entre iguais. Segundo Marilina Luz, o "aspeto mais importante que cumpre assinalar na atribuição de dom ao rei é, justamente, o facto de o rei ficar igualado, dentro de uns certos limites, a parte dos seus vassalos". Ainda segundo a mesma autora, quando se usava o Dom, a este seguia-se sempre o antropónimo e o patronímico. Contudo, no final do século $\mathrm{XV}$, “quando o dom, por mercê régia ou por outro motivo, passava a fazer parte do nome, o patronímico era abandonado" 102 . Na seriação para este artigo, uma ilação curiosa do uso do dom é, muitas vezes, a sua autoatribuição. Isto é particularmente evidente nos juramentos e depois nos cabeçalhos das correspondências. Egas Moniz, o aio de D. Afonso Henriques, era por todos tratado por Dom. No entanto, cabe aqui destacar uma passagem muito interessante. É Dona Leonor Teles a falar com um seu aio, "Dom David Negro, judeu arrabiado de Castela":

${ }^{101}$ BLUTEAU, Rafael - Vocabulario portuguez e latino... Tomo III. p. 283.

${ }^{102}$ LUZ, M. S. - Fórmulas de Tratamento no Português Arcaico. pp. 101; 115. 
Aqui estaaes vos, dom David! e vos me fazeees aqui viinr! [...] Oo perro cam treedor! e tu disseste aquello de mim? [...] Memtes, [...] E sse assi passou de feito, tu mo comsselhaste (... $)^{103}$.

O que se vê neste excerto é, precisamente, um carrossel de formas de tratamento do mais polido ao mais impositivo. É que este judeu tinha denunciado o mirabolante plano de assassinato de João I de Castela ao próprio, e este, incrédulo, pediu esclarecimentos a Dona Leonor. É assim que se deve entender a postura estratégica de Dona Leonor em primeiro tratá-lo bem para que ele desmentisse o dito. Mas como ele não o fez, foi-se tornando progressivamente mais direta e até passou a cometer a falácia de atacar o indivíduo para descredibilizar o seu argumento. Aqui se observa toda a riqueza e dinâmica da variação linguística.

Ironicamente, D. Afonso Henriques tratou um cardeal por Dom Cardeal ${ }^{104}$. Segundo Marilina Luz, dar a uma pessoa um "tratamento muito superior ao que ela merece é, de certo modo, ridicularizá-la, visto que se põe em evidência a sua condição de inferioridade. Assim se explica o dom, dado por ironia". Associar dom a "uma palavra ou expressão que o tornassem despropositado" vinha intensificar a ironia ou o insulto. ${ }^{105}$ Também para Cláudio Basto, dar "forma muito mais elevada do que à sua categoria (ou à intimidade havida) compete, é sinal de contundente ironia" ${ }^{" 106}$. Seja como for, dom, pequena partícula de cortesia, tanto podia ter o seu uso justificado em honra de alguém, como por vezes poderia adquirir a sua faceta de ironia e despropósito.

No que se refere a dona, naquele mesmo dicionário é definida como título de "molher nobre" ${ }^{107}$. Segundo Marilina Luz, entre a primeira nobreza, era um prenome dado à rainha, às filhas dos reis, a mulheres nobres, a mulheres viúvas, a solteiras e a crianças. Contudo, acontecia de também ser aplicado para com senhoras não tão nobres e sem direito para o usar. Para ela, quando "um escritor medieval empregava o termo dona devia obedecer ao desejo de evitar uma palavra como mulher, considerada, provavelmente, como ainda hoje, menos delicada, por ser demasiado geral”. A “situação social da mulher casada e da mulher viúva, tornando-as mais dignas do respeito e da consideração alheias, teria favorecido a sinonímia acidental «dona=mulher casada» e «dona=mulher viúva». O mesmo quanto a «dona=religiosa»". Dona era uma regalia cobiçada. ${ }^{108}$

Outros vocábulos se somaram a dona, quer intensificando-o quer desvalorizando-o, quer adjetivos quer nomes como senhora. Disto é exemplo boa dona, tratamento empregue pelo Infante

\footnotetext{
${ }^{103}$ LOPES, F. - Crónica de D. João I - parte I. Cap. LXXXIII; p. 140; Linhas 24; 29; 32.

${ }^{104}$ LOPES, F, - Crónica de Portugal 1419. Cap. 18; p. 31; Linha 13.

${ }^{105}$ LUZ, M. S. - Fórmulas de Tratamento no Português Arcaico. p. 112.

106 BASTO, C. - Formas de tratamento, em português... pp. 183-184.

${ }^{107}$ BLUTEAU, Rafael - Vocabulario portuguez e latino... Tomo III. pp. 287-288.

${ }^{108}$ LUZ, M. S. - Fórmulas de Tratamento no Português Arcaico. pp. 153-158.
} 
D. João, filho de D. Pedro I e Inês de Castro, para com Dona Maria Teles, de quem se tinha aproximado, mas que por instigar de Leonor Teles, ia matar. Ela sempre o tratou por senhor ${ }^{109}$ :

Boa dona, agora o saberees: vós andastes dizendo $(\ldots)^{110}$.

Seria interessante ter registo de um diálogo anterior entre os dois. É que segundo Marilina Luz, boa dona era já ligeiramente depreciativo ${ }^{111}$. E isso até pode ser verídico, dado que este foi proferido momentos antes de a matar, mas na ausência de registos não se pode passar da suposição.

\subsection{Outras}

As formas de tratamento deste tópico são de ocorrência ocasional, mas é nele que se demostra a extraordinária diversidade do rol de tratamentos passíveis de ser empregues no quotidiano medieval. São tratamentos avulsos e momentâneos que para alguns autores sequer mereceriam a consideração de tratamento. Nesta condição estão os tratamentos por nomes de parentesco, hierarquia, cargo e funções. A distribuição quantitativa é apresentada em quadro anexo no final.

Inicialmente, segundo Marilina Luz, padre era uma forma reverenciosa de se dirigir, por escrito, ao Papa. Como em todos os tratamentos, porém, também ele foi sendo progressivamente alargado. Madre, por sua vez, que também estava reservado a eclesiásticas, experimentou o mesmo processo. Para aquela autora, "Padre e madre desceram no tratamento eclesiástico no mesmo século em que foram substituídos, definitivamente, por pai e mãe como designação dos progenitores e como tratamento que lhes é dado pelos filhos" ${ }^{" 12}$. No núcleo familiar, a eles poderiam somar-se possessivos ou adjetivos. Seja como for, o que ressuma do pouco uso deste tratamento é que os filhos chamavam os pais mais respeitosamente por senhor e senhora. Pai e mãe parece que ainda estavam a começar a surgir, dados os escassos exemplos colhidos, aliando-se primeiro a senhor e senhora, para só depois usar-se em avulso ${ }^{113}$. Curiosamente, também havia o costume de chamar padre ao sogro, filho ao genro, irmão ao cunhado e madre à sogra. Os cunhados também se tratavam por irmãos. De cunhado para cunhada, sobretudo se ela era rainha, observa-se maior cortesia. Ela podia tratá-lo por irmão, mas ele replicava com senhora.

Nuno Álvares Pereira tratava o seu irmão e prior da Ordem do Hospital, Pedro Álvares Pereira, por irmão senhor, ao passo que este último replicou, rindo, apenas como irmão:

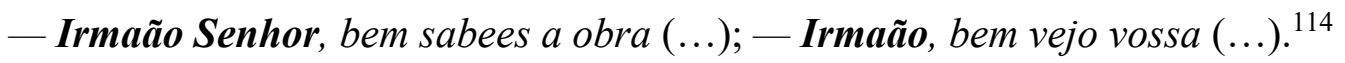

\footnotetext{
${ }^{109}$ LOPES, F. - Crónica de D. Fernando. Cap. CIII; p. 371; Linha 71. Quadro 9, n. ${ }^{\circ} 158$.

${ }^{110}$ LOPES, F. - Crónica de D. Fernando. Cap. CIII; p. 371; Linha 72.

${ }^{111}$ LUZ, M. S. - Fórmulas de Tratamento no Português Arcaico. p. 160.

${ }^{112}$ LUZ, M. S. - Fórmulas de Tratamento no Português Arcaico. p. 150.

${ }^{113}$ A este respeito veja-se o capítulo 97 do Leal Conselheiro, em que D. Duarte descreve a relação para com D. João I, seu pai. Cf. D. DUARTE - Leal Conselheiro, o qual fez Dom Duarte... pp. 458-475.

${ }^{114}$ LOPES, F. - Crónica de D. Fernando. Cap. CXXII; p. 435; Linha 8. Noutro diálogo inverteu, chamou-o por Senhor Irmão. Ver na mesma crónica o Cap. CLI, p. 525 linha 24 e p. 526 linha 37.
} 
Exemplo de parentesco por extensão é a forma como Dona Leonor Teles se dirigiu ao futuro D. João I, então ainda mestre de Avis, e este responder usando de senhora:

Irmaão amigo, bem sabees que aos mall-dizentes nunca lhes mingua que digam (... $)^{115}$. Igualmente por extensão, Dona Leonor para com João I de Castela e a resposta deste: — Filho senhor, encomendo a Deus e a vós (...); - Madre senhora, eu lhe entendo ....). ${ }^{116}$

D. Afonso Henriques tratava D. Sancho por filho, que lhe replicava sempre com senhor: Filho, tu sabes bem quamto trabalho $(. . .)^{117}$.

São vários os exemplos para filho e filha. No entanto, enquanto que os pais usam o tu principal ou auxiliarmente, as mães empregam o vós.

Dona Constança Manuel tratava o seu pai como: Padre e senhor $(\ldots)^{118}$.

Irmão e irmã também foram usadas no meio eclesiástico. Nestas relações parece reinar a solidariedade de Roger Brown e Albert Gilman, dado que era um tratamento de superior para inferior e/ou de igual para igual em que se demostra alguma condescendência ${ }^{119}$. Para Marilina Luz, "A igualdade espiritual que estas locuções de tratamento traduzem não podia conciliar-se com a necessidade de manter uma certa diferenciação, necessidade que se verifica mesmo no meio eclesiástico" ${ }^{120}$. Fora desse meio, irmão e irmã foi tratamento comum entre aqueles que efetivamente o eram. Contudo, se o filho fosse rei, a mãe fazia-o seguido de senhor. Igual para irmão senhor.

Fora do meio eclesiástico, mas mais uma vez dentro do conceito de solidariedade daqueles autores, é evidente o uso de irmão e filho entre quem não tinha consanguinidade efetiva. No que se refere a irmão, Marilina Luz escreveu que "A amizade ou a camaradagem tornavam natural este tratamento". A sua sublimação é particularmente evidente aquando de momentos aflitivos, de que são exemplo as numerosas ocorrências já relatadas de Nuno Álvares Pereira a chamar de amigos e irmãos os seus companheiros. Por seu lado, filho que ainda "não se tinha ainda banalizado no português medieval", sendo visível nalguns casos de pessoas mais velhas para com mais novos entre os quais havia alguma cumplicidade. ${ }^{121} \mathrm{O}$ que demonstram os tratamentos seriados é que, a despeito da intimidade, estes eram primacialmente pautados pelo respeito que inspiram os mais velhos.

Ainda entre as relações familiares, há o caso de compadre e comadre, que muitas vezes também era usado por quem não o era de facto. Pode dizer-se que há uma certa irmandade inerente

\footnotetext{
${ }^{115}$ LOPES, F. - Crónica de D. Fernando. Cap. CXLVI; p. 511; Linha 57. Noutro momento até o tratou só por Irmão.

${ }^{116}$ LOPES, F. - Crónica de D. Fernando. Cap. CLXVI; p. 572; Linhas 43 e 52.

${ }^{117}$ LOPES, F. - Crónica de Portugal 1419. Cap. 38; p. 67; Linha 1. Poder-se-iam citar, pelo menos, mais duas ocorrências.

${ }^{118}$ LOPES, F. - Crónica de Portugal 1419. Cap. 139; p. 226; Linha 22.

119 BROWN, R.; GILMAN, A. - The Pronouns of Power and Solidarity.

${ }^{120}$ LUZ, M. S. - Fórmulas de Tratamento no Português Arcaico. p. 148.

${ }^{121}$ LUZ, M. S. - Fórmulas de Tratamento no Português Arcaico. pp. 195, 201-202.
} 
ao tratamento. No entanto, para além de usado por quem o podia fazer por direito e por quem não tinha qualquer ligação efetiva, Marilina Luz nele identificou uma dimensão jocosa. Compadre ou comadre "Devia ser tratamento levemente jocoso, pelo menos na forma masculina"122. Disto é exemplo uma passagem relatada por Fernão Lopes, em que um chamado de Anequim, jogral que vivera na corte de D. Fernando e Dona Leonor, tinha por costume chamar de compadre a qualquer que conhecia e assim chamavam os outros a ele. De facto, ele assim foi tratado uma vez $^{123}$. Porém, ele mesmo tratou o conde de Mayorgas, bastardo de João Nunez de Lara, por senhor ${ }^{124}$. Também se flagraram-se tratamentos consoante as dignidades eclesiásticas. É o caso de cardeal, bispo, prior, mestre, e até um caso de extrema cortesia:

Bispo Valerio, padre, per tua liçemça $(. . .)^{125}$; Cardeal, em como eu sam irege (...) $)^{126}$; prioll, vos dires a uosso senhor $(. . .)^{127}$; Muy nobre senhor bispo, àquelas cousas que $(\ldots)^{128}$.

Também se encontraram formas de tratamento a partir das atribuições, como no caso de comendador, almirante, cavaleiro ou escudeiro:

Comemdador, nom sejaaes triste (...) ${ }^{129} ;$ Almiramte, [...] o vosso dizer he mui boom $(. . .)^{130}$; Cavalleiro, vos nom vos agravees $(. . .)^{131}$; Escudeiro, segundo vos $(\ldots)^{132}$.

Nalguns casos, a cavaleiro se podiam somar vários níveis de adjetivação conforme o valor de cada sujeito ${ }^{133}$. Excecionalmente, porque apenas se colheram dois exemplos, Nuno Álvares foi tratado sempre pelo mesmo trombeta mensageiro como:

Senhor Condestabre (... $)^{134}$; e respondia-lhe como amigo.

Único é o caso de doutor, usado por um bispo próximo ao Duque de Lencastre para com o "doutor em lex e degredos", Álvaro Martins: Doutor uos dizees em nome de uoso $(\ldots)^{135}$.

Disse D. João ainda mestre ao conde de Barcelos, João Afonso Telo: Conde, hiivos $(\ldots)^{136}$. Outro exemplo ocasional é príncipe, apesar de se esperar maior uso. No primeiro tem-se Fernão Peres de Trava a dirigir-se a D. Afonso Henriques, e no segundo um ermita ao mesmo rei:

\footnotetext{
${ }^{122}$ LUZ, M. S. - Fórmulas de Tratamento no Português Arcaico. p. 211.

${ }^{123}$ LOPES, F. - Crónica de D. João I - parte I. Cap. LXX; p. 120; Linha 31.

${ }^{124}$ LOPES, F. - Crónica de D. João I - parte I. Cap. LXX; p. 121; Linha 18.

${ }^{125}$ LOPES, F, - Crónica de Portugal 1419. Cap. 15; p. 26; Linha 5.

${ }^{126}$ LOPES, F, - Crónica de Portugal 1419. Cap. 18; p. 31; Linha 16.

${ }^{127}$ LOPES, F. - Crónica de D. João I - parte II. Cap. LXXXI; p. 193; Linha 3.

${ }^{128}$ LOPES, F. - Crónica de Portugal 1419. Cap. 165; p. 266; Linha a confirmar.

${ }^{129}$ LOPES, F. - Crónica de D. João I - parte I. Cap. XCIX; p. 166; Linha 20.

${ }^{130}$ LOPES, F. - Crónica de D. João I - parte I. Cap. CXXIX; p. 222; Linha 40.

${ }^{131}$ LOPES, F. - Crónica de D. João I - parte I. Cap. XCVIII; p. 165; Linha 19.

${ }^{132}$ LOPES, F. - Crónica de D. João I - parte II. Cap. CLXV; p. 348; Linha 23.

${ }^{133}$ BEIRANTE, M. Â. - As Estruturas Sociais em Fernão Lopes. p. 36.

${ }^{134}$ LOPES, F. - Crónica de D. João I - parte II. Cap. LV; p. 135; Linha 2. Poder-se-iam citar, pelo menos, mais duas ocorrências.

${ }^{135}$ LOPES, F. - Crónica de D. João I - parte II. Cap. LXXXII; p. 193; Linha 30.

${ }^{136}$ LOPES, F. - Crónica de D. João I - parte I. Cap. IX; p. 18; Linha 4.
} 
Primçepe, nom andemos neste $(. . .)^{137} ;$ Primçepe dom Afonso $(\ldots)^{138}$.

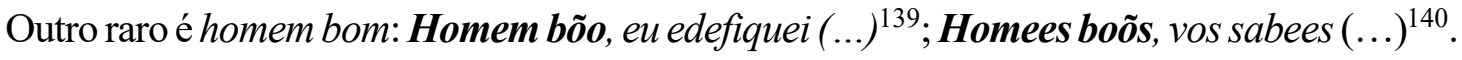

Outros exemplos são traidor ${ }^{141}$ e varão ou, mais precisamente, "varom"142.

Quando o responsável inglês pelo casamento de Dona Beatriz, filha de D. João I, tratou-a oralmente por Muy nobre e honrrada senhora dona Breatiz $(. . .)^{143}$, estava apenas a reproduzir um tratamento evidentemente aplicado apenas ao registo escrito.

\subsection{Nome próprio}

Apesar de não ser o enfoque deste estudo, o tratamento pelo nome próprio não podia deixar de ser notado, posto que é também uma forma de tratamento possível. É que tratar alguém pelo nome próprio implica ou intimidade ou superioridade para com o interlocutor. A maior curiosidade relacionada à seriação realizada prende-se com o facto de ao antropónimo se seguir sempre o patronímico, entre iguais e de superior para inferior, quando não se usava o tratamento senhor.

Marilina Luz considerou o tratamento com o nome próprio seguido do apelido meio atencioso e o tratamento com apenas o nome de batismo como revelador de "familiaridade franca sem-cerimónia". Por norma, com nome + apelido a frase era construída com a segunda pessoa do plural vós, ao passo que usar apenas o nome de batismo dependia de um $t u .{ }^{144}$ Apesar de nos exemplos seguintes isso não se vislumbrar, havia a possibilidade de ao nome se fazer anteceder partículas de tratamento que tornavam o tratamento mais cerimonioso. Outro destaque atém-se com o facto de aos homens se chamar com uso do antropónimo e do patronímico, enquanto que para as mulheres se limitar ao nome próprio. São geralmente entre íntimos ou de superior para inferior, mas nunca um rei foi tratado pelo nome - pelo menos no corpus estudado.

Nuno Álvares Pereira tratava D. Fernando por senhor, mas este chamava-o pelo nome: Nun'Allvarez, eu vejo bem vossa enteençom (...) ${ }^{145}$.

Numa longa conversação entre Dona Leonor Teles e o seu meio-irmão Gonçallo Vaasquez d'Azevedo, este tratou-a sempre por senhora, e esta replicou com o seu nome:

Gonçallo Vaasquez, eu bem ssei que vossa molher vos disse (... $)^{146}$.

\footnotetext{
${ }^{137}$ LOPES, F, - Crónica de Portugal 1419. Cap. 6; p. 10; Linha 11.

${ }^{138}$ LOPES, F, - Crónica de Portugal 1419. Cap. 14; p. 20; Linha 25.

${ }^{139}$ LOPES, F, - Crónica de Portugal 1419. Cap. 31; p. 54; Linha 9.

${ }^{140}$ LOPES, F. - Crónica de D. João I - parte I. Cap. XXIX; p. 52; Linha 36.

${ }^{141}$ Ver LOPES, F. - Crónica de D. Fernando. Cap. XXIII; p. 83; Linha 74. - Crónica de Portugal 1419. Cap. 18; p. 30; Linha 29. - Crónica de D. João I - parte I. Cap. CII; p. 174; Linha 30.

${ }^{142}$ Ver Crónica de D. João I - parte II. Cap. LXIV; p. 154; Linha 29.

${ }^{143}$ LOPES, F. - Crónica de D. João I - parte II. Cap. LXXXI; p. 193; Linha 3.

${ }^{144}$ LUZ, M. S. - Fórmulas de Tratamento no Português Arcaico. p. 193.

${ }^{145}$ LOPES, F. - Crónica de D. Fernando. Cap. CCIV; p. 460; Linha 23.

${ }^{146}$ LOPES, F. - Crónica de D. Fernando. Cap. CXXXIX; p. 489; Linha 58.
} 


\section{Fórmulas de tratamento}

Como se disse, entende-se por fórmulas de tratamento aquelas expressões mais características do registo escrito presentes maioritariamente em correspondências, ou seja, expressões formulares ou previamente compendiadas e selecionadas conforme o destinatário. De forma sucinta, de seguida se intenta uma breve descrição daquelas fórmulas que predominantemente compunham o protocolo dos textos epistolares. O facto de a maior parte dos tratamentos formulares recolhidos constar da Crónica de D. Pedro I poderá ter que ver com as fontes consultadas pelo cronista para a redação dessa crónica. Como explicou Peter Russel, em comparação com as outras, na Crónica de D. Pedro I as fontes foram essencialmente cartas e ofícios que refundiu ${ }^{147}$. Aliás, que trelladou.

Uma característica do registo escrito é a identificação do remetente, à que se pode seguir fórmula de humildade ou de devoção. Outra é o facto de, não poucas vezes, as correspondências serem lidas em voz alta e até terem serem discutidas. Como a escrita é mais pensada do que a fala, a probabilidade de invocar um tratamento mais conforme ao destinatário é maior. Sabendo que, mais tarde, D. Afonso $\mathrm{V}$ estabelecerá ditados especiais para doze reinos, proceder-se-á por retrospetiva e em ordem decrescente de importância: poderoso, alto, excelente, ilustre, nobre e honrado ${ }^{148}$. A estas expressões somava-se uma forma de tratamento como príncipe, por exemplo, a mais comum.

No que se refere à designação de si próprio, ou seja, à subscrição/intitulatio, esta é menos sujeita a variação, dado que quem escreve não se quer subtrair de honra. Os Papas nomeiam-se sempre de: Johanne bispo, servo dos servos de Deus (... $)^{149}$.

Sempre, com exceção de um: Ynoçençio, papa, servo dos servos de Deos $(\ldots)^{150}$.

Os nobres, reis e não reis, invocam a sua ascendência, condição ou ambos. Por exemplo, no primeiro tem-se D. João ainda como regedor e defensor do reino, e no segundo já como rei: Dom Joham pella graça de Deos, filho do mui nobre Rei dom Pedro, Meestre da Cavallaria da Hordem dAvis, Regedor e Defemssor dos rregnos de Portugal e do Algarve. (...)"151 e

Dom Joham, pella graça de Deus Rey de Portugall e do Algarue (...) ${ }^{152}$.

Há maior heterogeneidade, evidentemente, nos destinatários. Os Papas são semelhantes: muito amado em Christo filho dom Pedro mui nobre rrei de Purtugall (... $)^{153}$ e muito amado em Christo nosso filho mui claro rrei de Putugall e do Algarve Affonso (... $)^{154}$.

\footnotetext{
${ }^{147}$ RUSSEL, P. - As Fontes de Fernão Lopes. p. 17.

${ }^{148}$ LUZ, M. S. - Fórmulas de Tratamento no Português Arcaico. p. 91.

${ }^{149}$ LOPES, F, - Crónica de D. Pedro I. Cap. XXVIII; p. 128; Linha 87. Poder-se-iam citar, pelo menos, mais nove exemplos.

${ }^{150}$ LOPES, F, - Crónica de Portugal 1419. Cap. 70; p. 129; Linha 4. Quadro 16, n. ${ }^{\circ} 385$.

${ }^{151}$ LOPES, F. - Crónica de D. Fernando. Cap. XXVII; p. 48; Linha 26.

${ }^{152}$ LOPES, F. - Crónica de D. João I - parte II. Cap. II; p. 7; Linha 12.

${ }^{153}$ LOPES, F. - Crónica de D. Pedro I. Cap. III; p. 15; Linha 8-10.

${ }^{154}$ LOPES, F. - Crónica de D. Pedro I. Cap. XXVIII; p. 128; Linha 89.
} 
De forma semelhante, Pedro IV de Aragão tratou D. Pedro I:

Muito alto e muito nobre dom Pedro, pella graça de Deus rrei de Purtugall e do Algarve (... $)^{155}$

Já o duque de Génova, suplicante, tratou D. Pedro por: Príncipe e senhor mui claro, de grande e rreal majestade $(. . .)^{156}$.

O mais extraordinário dos exemplos estudados evidenciou-se numa carta do Papa Honório III a D. Sancho II. Apesar de ser comum os Papas tratarem os demais por tu, é notável o facto do Papa se recusar a dar o tratamento costumeiro a D. Sancho II por causa do seu comportamento e que resultou em excomunhão. É ilustrativo da importância que o formulário tinha à época: ao nobre rey de Portugal. Esprito de mais são conselho aquele que em ti he nos demoveo que nom puseçemos aquy a palavra com que te acostumavamos a saudar porque a tua culpa, que he muyto de doer, a qual te apartou da companhya dos fieys, te foy e he mereçedor desto, que bem devias tu de saber que todo poderyo he dado de Deos, o qual soo tem poder do reyno dos homens e alevanta em ele quem lhe apras. E porem tu, com hi poderio da tua $(. . .)^{157}$.

Curiosa, mas compreensivamente, às rainhas estrangeiras não equivaliam os epítetos dos maridos. Eram "muito altas, e muito excelentes", às quais se juntavam construções com o possessivo vossa. No tratamento epistolar também era normal empregar amigo para com outros reis, nobres e clérigos. Porém, o facto "de o rei não a usar em cartas dirigidas ao Papa", revela que esta era um tratamento "entre iguais ou de superior para inferior". "Também em cartas dirigidas a senhoras, o rei não escrevia amiga, tratamento que trairia familiaridade despropositada e (...) falta de delicadeza". ${ }^{158}$

\section{Formas e fórmulas de tratamento em orações}

No corpus analisado, em orações o tu é predominante. Já não era o tu universal e aplicado a todos indistintamente conforme o paradigma latino, mas era o $t u$ de intimidade que dividia o espaço da segunda pessoa do singular com o vós de cortesia, reverência ou respeito. Porém, como foi exposto, o que se passou foi o vós ultrapassar o tu em frequência, mesmo entre íntimos e familiares, sendo este progressivamente restrito nos seus destinatários e/ou limitado ao tratamento de superior para inferior.

Como entender que $t u$ fosse usado para com a divindade quando para com esta se esperaria a maior das reverências? Como se manteve $t u$ para com Deus e santos, se este mesmo $t u$ era tido como grave e desrespeitoso de inferior para superior, ao ponto de nem os filhos tratarem os pais por $t u$ ? A resposta a estas questões nem o professor Lindley Cintra alcançou, dispensando, desde logo, a possibilidade da influência de textos litúrgicos. Quanto ao uso do vós da segunda pessoa

\footnotetext{
${ }^{155}$ LOPES, F. - Crónica de D. Pedro I. Cap. III; p. 17; Linha 52-53.

${ }^{156}$ LOPES, F. - Crónica de D. Pedro I. Cap. X; p. 44; Linha 21.

${ }^{157}$ LOPES, F. - Crónica de Portugal 1419. Cap. 66; p. 120; Linha 18.

${ }^{158}$ LUZ, M. S. - Fórmulas de Tratamento no Português Arcaico. p. 185.
} 
do singular, portanto, de cortesia, em orações, encontrou o professor uma glosa ao Pater Noster, provavelmente da lavra do infante D. Pedro no seu Livro da Virtuosa Benfeitoria, em coexistência com outra que suspeita ser da lavra do confessor do infante, Frei João Verba, em que este usa o $t u$. É uma exceção. Nas cantigas, o vós que surge é o da segunda pessoa do plural, logo comum. ${ }^{159}$

A par do tu, usava-se Senhor, padre ou rei para Deus e Jesus Cristo associados a outros termos, e para a Virgem há um exemplo de madre. Observem-se alguns exemplos.

Disse Mestre Rodrigo de Sintra, da Ordem de São Francisco:

Beemto sejas Tu mui alto Deos, Primçipe dos reis da terra, doçe Sollaz dos atribullados; e muitas graças Te damos, que nos quiseste ouvir, e do favvo da Tua dulçura destillastes sobre nos atam gramde misericordia $(. . .)^{160}$.

Avizinhando a morte, clamou Dona Maria Telles de Meneses:

Madre de Deus, acorre-me e ave mercee (...) e Jesu filho da Virgem, acure-me (...). ${ }^{161}$

D. Afonso Henriques pediu:

Ho bõo Senhor Deos todo poderoso, a que obedeçem todalas criaturas e todas som a teu mandar e sob teu poderio, a ty soo agradeço (... $)^{162}$ e Santiaguo, Santa Maria Virgem bemaventurada, acorê-nos aqui. Mata-os, mata-os, nom seja tal que escape (...) $)^{163}$.

Como se sabe, o atual estado da língua difere do medieval. Porém, não se pense que a mudança foi linear. Pelo contrário, houve muitos avanços e recuos, mas o primeiro período de prevalência do vós sobre o tu em preces e orações foi, segundo Lindley Cintra, entre o final do século XVI e o início do XVII, regressando o tu no XVIII ${ }^{164}$, só contrariado pela direção da Igreja já no século XX.

\section{Conclusões}

Ao findar desta exposição, viu-se que nalgum momento impreciso, o paradigma latino de tratamentos se alterou com a entrada do vós, pronome da $2 .^{\mathrm{a}}$ pessoa do plural, no campo da $2 .{ }^{\mathrm{a}}$ pessoa do singular. Quer por causa ou em consequência, o então pronome da 2. ${ }^{a}$ pessoa do singular tu, restringiu-se. Resumiu-se a relações de intimidade e assimétricas, de superiores para inferiores, com o vós singular a adotar uma dupla faceta respeitosa e cerimoniosa entre iguais ou de inferiores para superiores, e a manter a neutralidade da sua forma plural. O português medieval era já recetor deste paradigma. Apesar disso, em casos muito particulares, e quando havia interesse, alguns interlocutores de maior estatuto não se coibiram de empregar o vós polido para com indivíduos estatutariamente inferiores. A isso deve somar-se os usos aos quais se antepunham outras formas como Senhor, por exemplo. Assim, é difícil apurar apenas um verdadeiro sentido e é certo que o seu valor,

${ }^{159}$ CINTRA, L. F. L. - Sobre «Formas de Tratamento» na Língua Portuguesa. pp. 73-80.

${ }^{160}$ LOPES, F. - Crónica de D. João I - parte I. Cap. CLI; p. 280; Linha 39.

${ }^{161}$ LOPES, F. - Crónica de D. Fernando. Cap. CII; p. 372; Linhas 100 e 103.

${ }^{162}$ LOPES, F. - Crónica de Portugal 1419. Cap. 14; p. 21; Linha 3.

${ }^{163}$ LOPES, F. - Crónica de Portugal 1419. Cap. 25; p. 44; Linha 6.

${ }^{164}$ CINTRA, L. F. L. - Sobre «Formas de Tratamento» na Língua Portuguesa. pp. 85-89. 
forma e uso tenham variado. Certo é que todas as formas de vós e derivados experimentaram assinalável amplitude de interlocutores e ocorrências. O singular, pela sua própria natureza mais polida e respeitosa, parece ter sido a mais transversal das formas. Isto, apesar de poder ser rapidamente posta de lado em favor do $t u$ em caso de altercações, desentendimentos ou alterações anímicas.

Se também aos reis era o vós naturalmente dirigido, eles quase nunca foram tratados por $t u$. Aliás, só o foram mesmo em situações pontuais. Já os reis, por norma, não tratavam nem clérigos nem ninguém por $t u$ - havia que manter as formalidades inerentes à função. Os fillhos nunca tratavam os pais por $t u$, mas é possível que os pais, reis ou não, por vezes o fizessem. Quanto às esposas não há dados, apesar de se poder especular que usassem vós, posto que se lhes dirigiam por Senhor. Paradigmáticos, porém, são os referidos diálogos de Dona Leonor Teles com o Conde Andeiro e com um judeu, quando trata o primeiro com um $t u$ de intimidade e o segundo, que começa por tratar com um respeitoso vós e com um Dom antes do seu nome, termina com um tu impositivo, demonstrativo do penhor emocional patente nos tratamentos. A verdade é que, à época, ao que parece, o tu não tinha emprego generalizado. Curiosamente era a forma de tratamento por excelência em orações.

Além disso, no seio familiar os pais também podiam tratar os filhos por filho/filha. Estes respondiam com vós, padre e/ou senhor, com outras combinações. As mães tratavam os filhos por senhor ou filho/filha, que replicavam madre e/ou senhora. Contudo, enquanto os pais usavam tu para com os filhos/as, as mães usavam vós. Muitas vezes, depois de casados, os cônjuges adotavam os pais e demais familiares um do outro, tratando-os conforme a relação sanguínea do seu par. Ou seja, madre sogra e/ou simplesmente chamar madre à sogra, padre ao sogro, filho ao genro e irmão ao cunhado. Porém, a tónica aqui parece, a despeito da intimidade, pautada pelo respeito que inspiram os mais velhos.

$\mathrm{Na}$ sincronia estudada notou-se também o surgimento dos tratamentos nominais, aqueles que ao isolar de uma qualidade do interlocutor pospuseram-se possessivos como vossa. Novidade primacialmente para os monarcas, frisando-se a sua mercê, alteza, senhoria e majestade, foram paulatinamente sendo alargadas e, consequentemente, substituídas e/ou reservadas. Mais cerimoniosas, vieram tomar parte do campo de emprego do vós singular. Vieram sublinhar a tendência para a individualização dos tratamentos e a maior distância entre locutores, até porque implicavam a seleção do verbo na $3 .^{a}$ pessoa. De tão significativas, tiveram mesmo de ser legisladas, como o foram pouco depois por D. Afonso V e mais tarde por Filipe II, restinguindo-as hierarquicamente.

Senhor era o tratamento por excelência empregue para com o rei, mesmo antes de vós e vossa mercê. Além dele, era também empregue por inferiores a superiores de quem estivessem na dependência, e para clérigos. Além disso, houve a particularidade de se somar a nomes de terras, lugares, epítetos ou outros adjetivos. Extremamente respeitoso, foi também bastante variado e amplo. 
Também se verificou a existência de numerosas expressões esporádicas empregues como tratamento. Como se viu, algumas delas são: amigo, dom, dona, compadre, homem e homem-bom; formas associadas a dignidades eclesiásticas e seculares como santo padre, cardeal, bispo, arcediago, mestre e priol, e condestável, conde, comendador, almirante, cavaleiro e escudeiro; formas familiares como padre, madre, irmão, filho e filha; além de doutor, vassalo, varão e traidor. Umas mais fixas do que outras, mais ou menos respeitosas e até irónicas. Sim, porque qualquer tratamento na direção de quem não o merecia ou associado a certos estados de espírito e/ou a gestos é passível dessa interpretação.

A predominância de tratamentos para indivíduos hierarquicamente mais elevados tem que ver com aqueles a quem Fernão Lopes decidiu dar voz. Como cronista da arraia-miúda, não se coibiu de, mesmo ao serviço da Coroa, e de maioritariamente dar destaque aos seus executores, de também dar voz àqueles inferiores na hierarquia social. É talvez por isso que se colheram tantas formas de inferior para superior quantas de superior para inferior, apesar de mesmo entre inferiores o vós ser o "normal".

Não havendo um código de tratamento fixado por escrito, ele existia na mente de todas as pessoas. Todas sabiam como se comportar e o que dizer. Quando o infringiam, como que eram punidas, mesmo que tacitamente. Diretamente relacionada a isso é a perceção de que os tratamentos se foram tornando cada vez mais indiretos, ao mesmo tempo que alargados e individualizados, num processo não linear. Concomitantemente, as alterações provocadas pelos novos usos de formas de tratamento existentes, e pelo surgimento de novas, fez com que se processarem alterações ao nível da sintaxe e da construção frásica que nem sempre foram fáceis e evidentes, de que é exemplo não só a evolução das formas verbais, como os lapsos de concordância.

Deseja-se que a análise empreendida tenha sido suficientemente elucidativa, por um lado, do fantástico mundo que as rodeia e, por outro, do exaustivo trabalho de seriação, catalogação e síntese. É evidente que há lapsos, imprecisões e falhas que se lamenta. Também se lamenta a inacessibilidade a obras como "De "eu” e "tu" a "majestade. Tratamentos de familiaridade e reverência de Manuel Said Ali Ida, Linguistique et histoire des moeurs de Christophe Nyrop, Die Syntax der Anrede in Portugiesischen, de Harri Meier, entre outras que, certamente, enriqueceriam o estudo. Seria muito interessante avançar na cronologia, numa perspetiva diacrónica, para ver o uso dos tratamentos na nova situação de reconfiguração dos poderes provocada pela ascensão de $\mathrm{D}$. Afonso $\mathrm{V}$, os enfrentamentos e arranjos entre a adequação das formas de tratamento reclamadas. Seria igualmente interessente proceder a uma análise dos gestos ou da mimica cortês que, muitas vezes, acompanha a fala e que foram triados, bem como uma abordagem às precedências. Como quer que seja, mero anão a ombros de gigantes, não se teve aqui a pretensão de abordar definitivamente a vastíssima temática das formas e fórmulas de tratamento. Longe de esgotada, se se tiver somado um grão - mesmo que de mostarda — ao conhecimento existente, não terá então sido em vão todo o empenho e esforço empreendidos. 


\section{Fontes}

AFONSO X - Las Siete Partidas del Rey Alfonso El Sabio: cotejadas con varios codices antiguos por la Real Academia de la Historia. Tomo II - Segunda e Tercera Partida; Tomo III - Partida Quarta, Quinta, Sexta y Septima. Madrid: Imprenta Real, 1807. 795 p.. Disponível em WWW: $<$ URL:http://fama2.us.es/fde/lasSietePartidasEd1807T2.pdf $\&$ http://fama2.us.es/fde/lasSietePartidasEd1807T3.pdf $>$.

D. DUARTE - Leal Conselheiro, o qual fez Dom Duarte, pela graça de Deos Rei de Portugal e do Algarve, e Senhor de Ceuta, a requerimento da minha muito excellente Rainha Dona Leonor sua mulher, seguido do Livro da Ensinança de Bem Cavalgar Toda Sella (...). ed. José Ignacio Roquete. Paris: Officina Typographica de Fain e Thunot, 1842. Disponível em WWW:<URL:https://archive.org/details/lealconselheiroo1854duar>.

LOPES, Fernão - Crónica de D. Pedro I. Ed. crítica, introd., glossário e índices de Giuliano Macchi; rev. Giuliano Macchi, Teresa Amado. $1^{\text {a }}$ ed. [Lisboa]: Imprensa Nacional-Casa da Moeda, 2007. 231 p..

- - Crónica de D. Fernando. Ed. crítica, introd., glossário e índices de Giuliano Macchi; rev. Giuliano Macchi, Teresa Amado. $2^{a}$ ed. rev. [Lisboa]: Imprensa Nacional-Casa da Moeda, 2004. 654 p..

- - Crónica del Rei dom João I de boa memória por Fernão Lopes - Parte Primeira. Reprodução fac-similada da edição do Arquivo Histórico Português (1915) preparada por Anselmo Braamcamp Freire. Prefácio por Luís F. Lindley Cintra. [Lisboa]: Imprensa Nacional-Casa da Moeda, 1977. 424 p.

- - Crónica del Rei dom João I de boa memória por Fernão Lopes - Parte Segunda. Copiada fielmente dos melhores manuscritos por William J. Entwistle. [Lisboa]: Imprensa Nacional-Casa da Moeda, 1968. 461 p..

- - Crónica de Portugal de 1419. ed. crítica com introdução e notas de Adelino de Almeida Calado. $1^{a}$ ed. Aveiro: Universidade de Aveiro, 1998. 309 p. ISBN 972-8021-58-5.

ZURARA, Gomes Eanes - Crónica da Tomada de Ceuta. Publicada por ordem da Academia das Ciências de Lisboa segundo os manuscritos n³68 e 355 do Arquivo Nacional por Francisco Maria Esteves Pereira. Lisboa: Academia de Ciências, 1915. 349 p..

\section{Bibliografia}

ACADEMIA REAL DAS SCIENCIAS, Commissão de Historia - Collecção de Livros Ineditos de Historia Portugueza, dos Reinados de D. Dinis D. Affonso IV. D. Pedro I. e D. Fernando. Lisboa: Academia Real das Sciencias, 1816. Tomo IV.

BASTO, Cláudio - Formas de tratamento, em português. Revista Lusitana [Em linha]. Vol. 29, n. ${ }^{\circ}$ 1-4 (1931), p. 183-202. Disponível em WWW:<URL:http://cvc.institutocamoes.pt/component/docman/doc_download/218-revista-lusitana-volumexxix.html>. 
BEIRANTE, Maria Ângela - As Estruturas Sociais em Fernão Lopes. [Lisboa]: Livros Horizonte, 1984. 104 p..

BLUTEAU, Rafael - Vocabulario portuguez e latino... Tomo III. [Em linha]. Coimbra: Collegio das Artes da Companhia de Jesus, 1713. Disponível em WWW:<URL:http://purl.pt/13969/4/>.

BROWN, Penelope; LEVINSON, Stephen. Politeness: some universal in language usage. Cambridge: Cambridge University, 1987. 345 p.

BROWN, Roger; GILMAN, Albert - The Pronouns of Power and Solidarity. In SEBEOK, T.A. (ed.). Style in Language. [Em linha]. Massachusetts: MIT Press, 1960. p. 253-276. Disponível em WWW:<URL:https://doi.org/10.1515/9783110805376.252>.

CARDEIRA, Esperança - Revisitando a periodização do Português: o Português Médio. Revista Domínios de Lingu@gem. [Em linha]. Minas Gerais: Editora da Universidade Federal de Uberlândia. vol. 3, No 2 (2011) pp. 103-120. Disponível em WWW:<URL: http://www.seer.ufu.br/index.php/dominiosdelinguagem/article/view/11508 $>$.

CARREIRA, Maria Helena Araújo - Formas de Tratamento no Português como Designação do Outro e de Si: Perspectivas de Investigação e Transposição Didática. [Em linha]. Paris: Universidade de Paris VIII, [s.d.]. Disponível em WWW:<URL:https://docplayer.com.br/62394758-Formas-de-tratamento-deportugues-como-designacao-do-outro-e-de-si-perspectivas-de-investigacao-etransposicao-didactica.html>.

CAVALHEIRO, Valéria Mourales - As diferentes regras de uso das formas tu e você e suas influências na compreensão de narrativas literárias: PB e PE. [Em linha]. Porto: Faculdade de Letras da Universidade do Porto, 2017. 338 p. Tese de Doutoramento. Disponível em WWW:<URL:https://hdl.handle.net/10216/108454>.

CINTRA, Luís F. Lindley - Sobre «Formas de Tratamento» na Língua Portuguesa. [Lisboa]: Livros Horizonte, 1972. 144 p..

CUESTA, Pilar Vázquez; LUZ, Maria Albertina Mendes da - Gramática da Língua Portuguesa. Trad. Maria Gabriela Ardisson Pereira de Matos. Lisboa: Edições 70, [imp.] 1988. 704 p..

DUARTE, Isabel Margarida - Formas de Tratamento em Português: entre Léxico e Discurso. Matraga - Revista do Programa de Pós-Graduação em Letras da UERJ. [Em linha]. Rio de Janeiro: Instituto de Letras da UERJ. vol. 18, N. ${ }^{\circ} 28$ (2011) pp. 84-98. Disponível em WWW:<URL:https://www.e-publicacoes.uerj.br/index.php/matraga/article/view/26077> .

HOUAISS, Antônio; VILLAR, Mauro de Salles - Grande Dicionário Houaiss da Língua Portuguesa. Lisboa: Círculo de Leitores, 2015. vols. III, V.

LUZ, Marilina dos Santos - Fórmulas de Tratamento no Português Arcaico: subsídios para o seu estudo. Separata da Revista Portuguesa de Filologia. Coimbra: Casa do Castelo Editora, 1958. 283 p..

MARCOTULIO, Leonardo Lennertz - Formas de tratamento no português arcaico: contribuições do teatro português quinhentista. Confluência - Revista do Instituto de 
Língua Portuguesa. [Em linha]. Rio de Janeiro: Instituto de Língua Portuguesa do Liceu Literário Português. N. ${ }^{\circ} \quad 46 \quad$ (2014) Disponível em WWW:<URL:http://dx.doi.org/10.18364/rc.v1i46.14>.

MOREIRA, Filipe Alves - A Crónica de Portugal de 1419: fontes, estratégias e posteridade. [Lisboa]: Fundação Calouste Gulbenkian, 2013. 594 p.

MATTOSO, José (dir.) - A monarquia Feudal, Vol. 2 de MATTOSO, José e SOUSA, Armindo de, 'História de Portugal'’. Lisboa: Editorial Estampa, 1997.

MONTEIRO, João Gouveia - Fernão Lopes, texto e contexto. pref. José Mattoso. $1^{\text {a }}$ ed. Coimbra: Livraria Minerva, 1988. 164 p..

RUSSEL, Peter Edward - As Fontes de Fernão Lopes. Trad. de A. Gonçalves Rodrigues. $1^{\mathrm{a}}$ ed. Coimbra: Coimbra Editora Limitada, 1941. 52 p..

SAID ALI IDA, Manuel - Gramática Histórica da Língua Portuguesa. 2. edição melhorada e aumentada de Lexicografia, Formação de Palavras e Sintaxe do Português Histórico. [Em linha]. São Paulo: Companhia Melhoramentos, 1931. Disponível em WWW:<URL:https://archive.org/details/M.saidAli.grammaticaHistoricaDaLinguaPor ugueza/mode/1up $>$.

SARAIVA, António José; LOPES, Óscar - História da Literatura Portuguesa. $17^{\mathrm{a}}$ ed. corrigida e atualizada. Porto: Porto Editora, 2010. 1216 p..

SILVA, António de Morais - Grande Dicionário da Língua Portuguesa. 10a ed. Lisboa: Confluência, imp. 1959. vols. V, XII.

TEYSSIER, Paul - História da Língua Portuguesa. Trad. De Celso Cunha. $6^{\text {a }}$ ed. Lisboa: Livraria Sá da Costa, 1994. 114 p..

VASCONCELLOS, António Garcia Ribeiro de - Grammática histórica da língua portuguêsa (VI e VII classes do curso dos lyceus). Paris: Livraria Aillaud: 1900. 235 p.. Disponível em WWW:<URL:https://archive.org/details/grammticahist00vascuoft>.

VITERBO, Joaquim de Santa Rosa de - Elucidário das palavras, termos e frases que em Portugal antigamente se usaram e que hoje regularmente se ignoram. 2. a ed.. Lisboa: Editor A. J. Fernandes Lopes, 1865. 2 vols.. 
Anexos

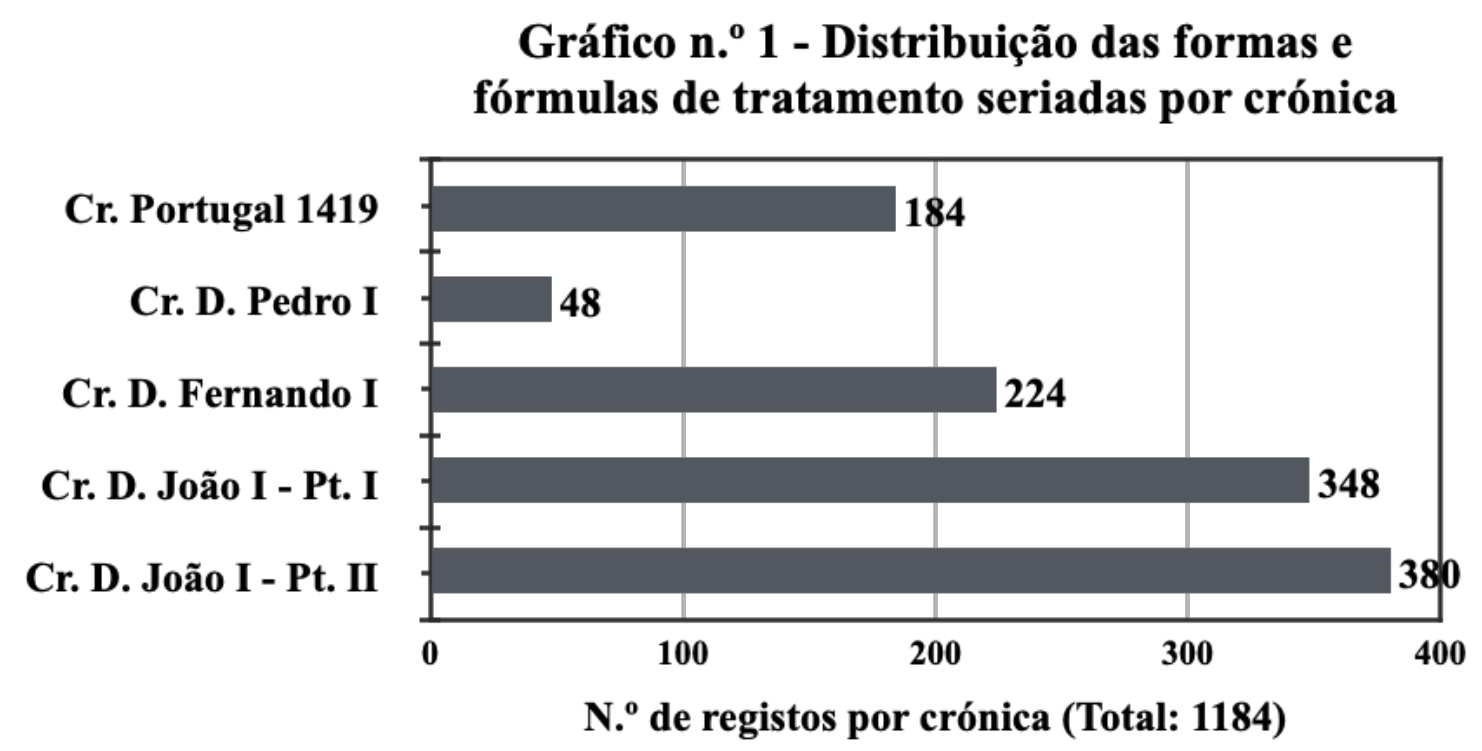

Gráfico n. 2 - Distribuição das principais formas de tratamento seriadas por tipo

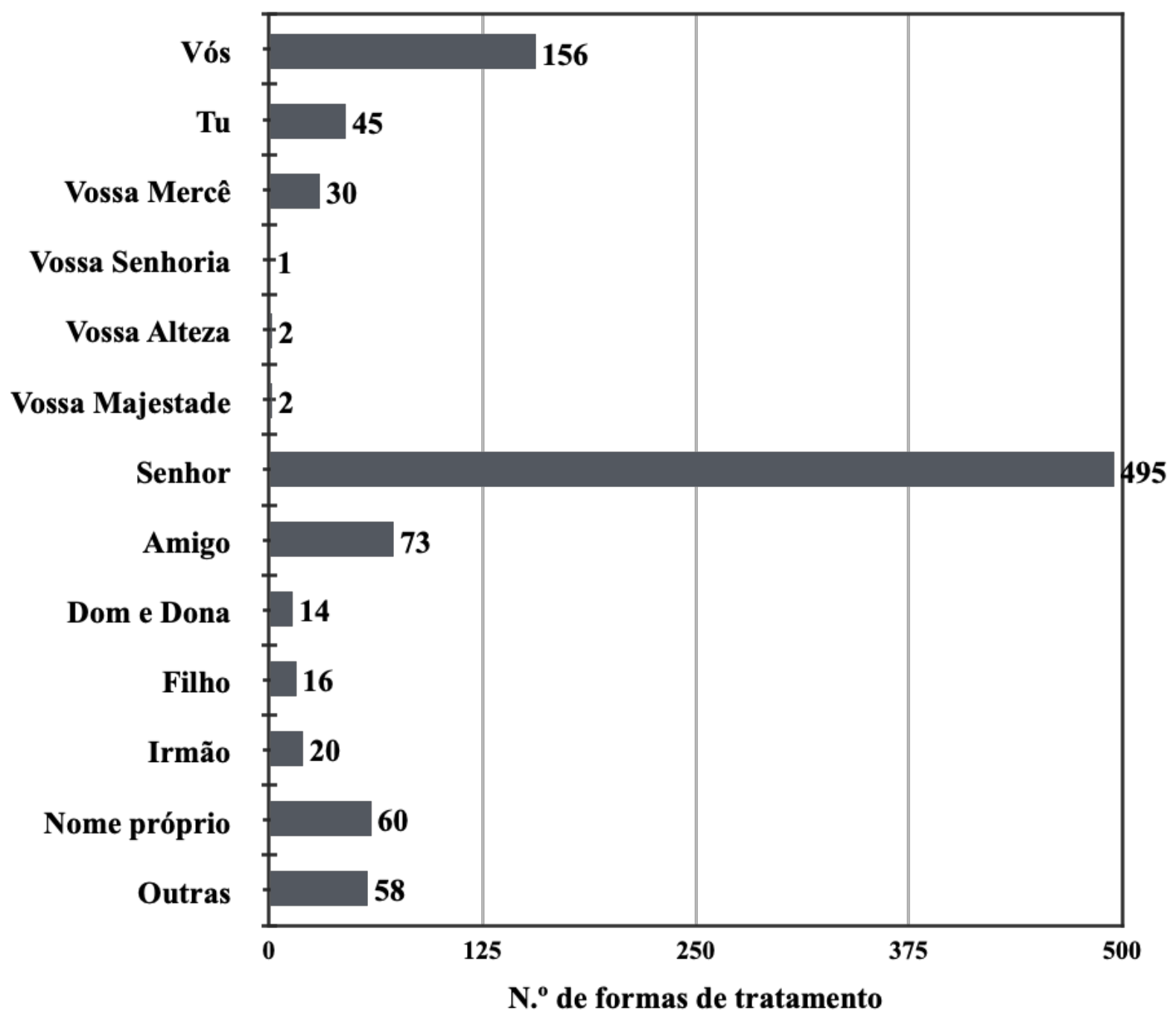


Gráfico n. ${ }^{\circ} 3$ - Distribuição das outras formas de tratamento seriadas por tipo

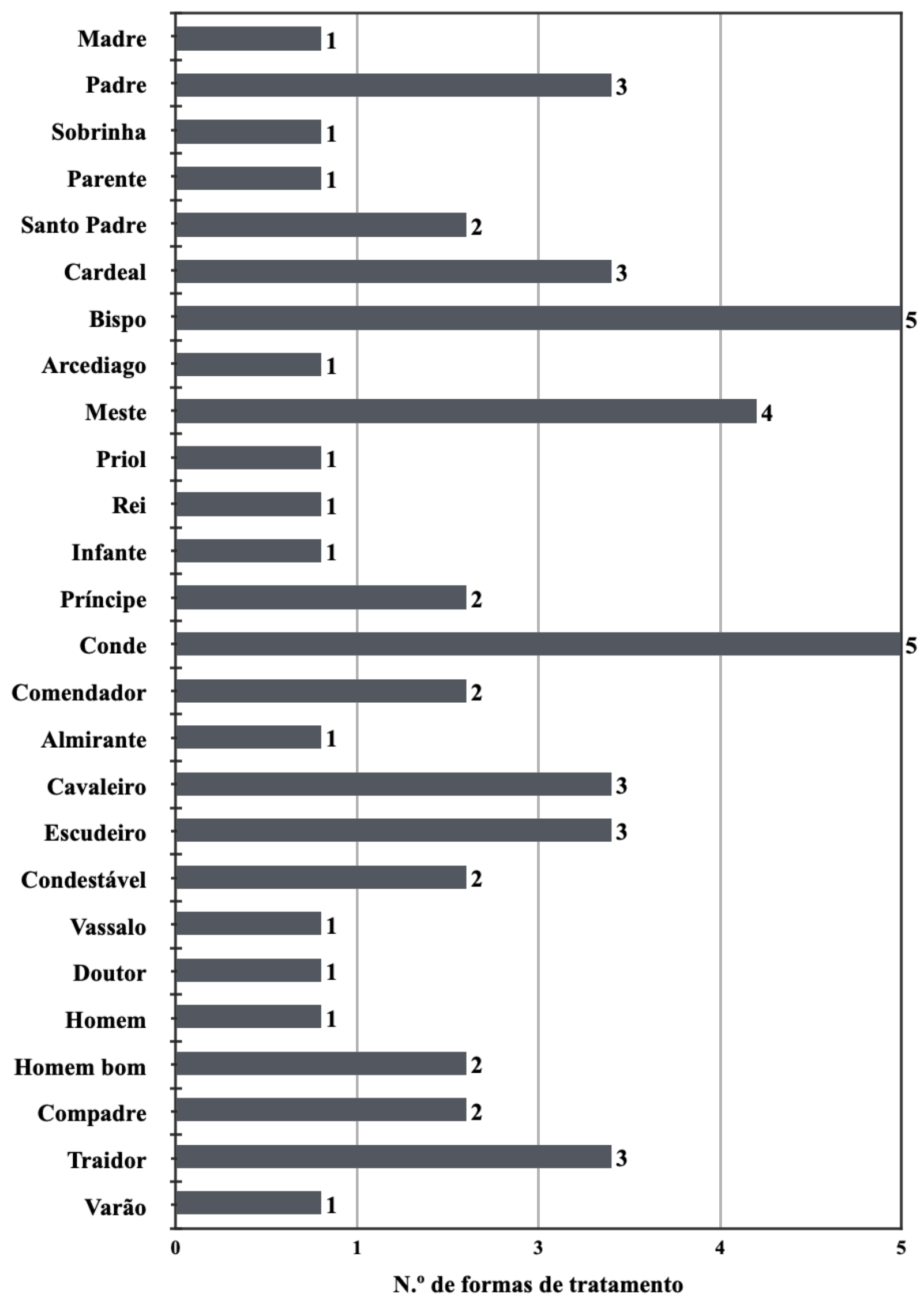

